\title{
光触媒による化学剤の分解
}

平川 力, 米良信昭, 佐野泰三, 根岸信彰, 竹内浩士*

\section{Decontamination of Chemical Warfare Agents by Photocatalysis}

\author{
Tsutomu Hirakawa, Nobuaki Mera, Taizo Sano, Nobuaki Negishi, and Koji TaKeuchi* \\ Research Institute for Environmental Management Technology, National Institute of Advanced \\ Industrial Science \& Technology (AIST), 16-1 Onogawa, Tsukuba, Ibaraki 305-8569, Japan
}

(Received August 15, 2008)

\begin{abstract}
Photocatalysis has been widely applied to solar-energy conversion and environmental purification. Photocatalyst, typically titanium dioxide $\left(\mathrm{TiO}_{2}\right)$, produces active oxygen species under irradiation of ultraviolet light, and can decompose not only conventional pollutants but also different types of hazardous substances at mild conditions. We have recently started the study of photocatalytic decontamination of chemical warfare agents (CWAs) under collaboration with the National Research Institute of Police Science. This article reviews environmental applications of semiconductor photocatalysis, decontamination methods for CWAs, and previous photocatalytic studies applied to CWA degradation, together with some of our results obtained with CWAs and their simulant compounds. The data indicate that photocatalysis, which may not always give a striking power, certainly helps detoxification of such hazardous compounds. Unfortunately, there are not enough data obtained with real CWAs due to the difficulty in handling. We will add more scientific data using CWAs in the near future to develop useful decontamination systems that can reduce the damage caused by possible terrorism.
\end{abstract}

Key words_— photocatalysis; titanium dioxide; chemical warfare agent; nerve gas; decontamination

\section{1. はじめに}

色素増感太陽電池などの光エネルギー変換材料と して，また環境污染物質を分解する環境浄化材料と して，近年，光エネルギーを受けて化学反応を引き 起こす光触媒が注目され，活発な研究開発がなされ ている.

光触媒としては取扱いの容易さから，金属酸化物 などの固体の半導体光触媒が好まれる．実際には光 触媒活性が高く，化学的に安定で，無害・無毒の酸 化チタン（ $\left.\mathrm{TiO}_{2}\right)$ がほとんどすべての場合に用い られている．波長 $400 \mathrm{~nm}$ 以下の紫外線が存在する 環境条件において，酸化チタンの表面には活性酸素 種が生成し，これがほとんどすべての有機物を分解 する環境浄化の駆動力となる. ${ }^{1,2)}$

筆者らは光触媒を大気污染物質に適用し, 窒素酸

産業技術総合研究所環境管理技術研究部門 ( $\bar{T} 305-$ 8569 茨城県つくば市小野川 16-1)

*e-mail: takeuchi-koji@aist.go.jp

本総説は, 日本薬学会第 128 年会シンポジウム $\mathrm{S} 10$ で 発表したものを中心に記述したものである.
化物のような酸化可能な無機ガスに加えて，多くの 低濃度の揮発性有機化合物（VOC）を前処理する ことなく酸化分解できることを示してきた. ${ }^{3)}-$ 方，光触媒は細菌やそれらが産生する毒素を破壊し て無害化する能力もある（抗菌作用として知られて (る)，処理対象は通常の環境污染物質に止まらな い訳で，非常事態における有害物質の処理にも利用 できる，軍の機関が研究資金を提供する欧米では， 早くからテロ対策技術の 1 つとして, 爆発物の処理 やサリンのような化学剤の分解の研究がなされてき たが，事情の異なる日本では皆無であった.

地下鉄サリン事件等を経験したわが国でも近年, 安全確保に対する意識が高まり，そのような分野に 対して研究開発費が配分されるようになった。本稿 は，科学警察研究所が取りまとめ機関として実施す るテロ対策研究において，光触媒の可能性を明らか にするために調査を行ったものである，光触媒は当 然ながら光が当たらないと機能しないなど，使用上 の制限・限界が多々ある。また，欧米の報告でも実 剤を使用しての研究報告は極めて限定されており， 
現時点での知見を明らかにすることは重要である.

ここでは，光触媒の原理や応用事例を紹介するとと もに, これまでの化学剤処理の研究事例を調査した 上で, 現在実施中の研究開発の方向性を展望するこ ととしたい.

\section{2. 光触媒について}

2-1. 光触媒の原理とメリット 半導体の電子 構造はバンド理論で説明される. Figure 1 に示すよ うに, 酸化チタンの場合, 価電子帯と伝導帯との禁 制帯幅（バンドギャップ）は波長約 $390 \mathrm{~nm}$ の紫外 線に相当する $3.2 \mathrm{eV}$ であり，価電子帯の電子はこ れよりも短波長の光子を吸収して伝導帯に上がるこ とができる.この酸化チタン粒子に電極が取り付け られていたならば，光照射による電流が観測される はずで，このものは紫外線センサーになり得るであ ろう。

酸化チタンが環境中にある場合には, 外部の物質 と直接, 電子の授受, すなわち酸化還元反応が起こ ることになる．環境中には酸素や水が多いので，こ れらが優先的に反応し, 強力な酸化剤である $\mathrm{OH}$ ラジカルや $\mathrm{O}_{2}^{-}$イオンが生成するとされる.これら の活性種の役割はいまだ十分に明らかにはなってい ないが, ${ }^{4)}$ 環境中では通常, 還元反応は起こらず, 酸化反応しか起こらない.

\section{$\mathrm{O}_{2}+\mathrm{e}^{-} \rightarrow \mathrm{O}_{2}^{-}$}

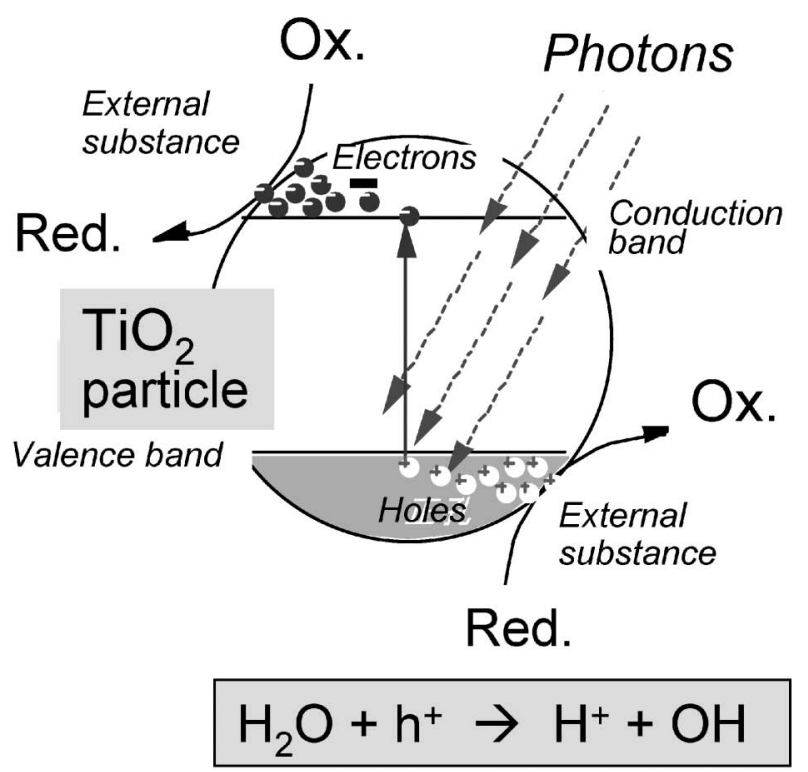

Fig. 1. Semiconductor Photocatalysis in the Environment
この機構により，光触媒に接触したほとんどすべ ての有機化合物は常温・常圧というマイルドな条件 で酸化され，最終的には二酸化炭素と水になる。し かし, 常温で用いることゆえに, 反応生成物が光触 媒上に残留したり，水蒸気などの影響を受け易いと いったデメリットもある。.また，光触媒の活性化に は光が必要なので，実用触媒で多用されるハニカム 構造などは採用し難い。光化学反応はデジタル的で あり，一般に，吸収された光子がある割合で反応を

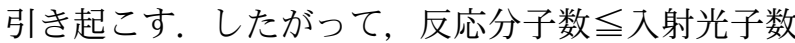
の制限がある．しかし，光が弱くても（入射光子数 が少なくても）それなりの量の物質を反応させるこ とができる.したがって，環境污染物質のように， $\mathrm{ppm}, \mathrm{ppb}$ といった低濃度の物質の処理には適して いるといえよう。

酸化チタンは太陽光に含まれる紫外線（波長 290$400 \mathrm{~nm}$ ）で機能するが，もし可視光でも機能する ならば光量から判断して性能は 1 桁向上すると考え られる。近年，生活環境への関心の高まりとともに 室内用途が注目されていることもあって，可視光応 答型光触媒の研究開発が盛んに進められている.5)

酸化于タンのような金属酸化物の表面は一般に親 水性であるが，光照射下では超親水性や両親媒性も 発現し，污れ防止（セルフクリーニング）に有効と されている.11

2-2. 光触媒の材料化 多くの金属酸化物 - 硫 化物は半導体であるが, 酸化チタンは強力な光触媒 活性に加えて，無害・無毒性，酸やアルカリに溶け ない化学的安定性，比較的安価で豊富な資源量とい つた優れた特性を有している，実際，われわれの生 活において，ほとんどの白いもの（塗料，紙，プラ スチック，化粧品，食品など）に酸化チタンが顔料 として添加されていることからも安全性が確認され る. 最も, 顔料用途では光触媒作用は不要であり, 粒子表面にアルミナやシリカをコーティングするこ とによって，光触媒作用を抑制している.

酸化チタンは通常, 白色の粉末である. 水質浄化 の初期の研究においては, 単に光触媒を水中に懸濁 させて処理していたが，実用的には，なんらかの方 法で物体の表面に付着させる必要がある。これま で，材料化が非常に難しかったのは，材料化により 酸化于タンの表面露出割合（=活性）が低下すると ともに，生成する活性酸素種が基材をも劣化させる 
Table 1. Immobilization Methods of Photocatalyst

\begin{tabular}{lllll}
\hline \hline \multicolumn{1}{c}{ Method } & Crude material & \multicolumn{1}{c}{ Example } & \multicolumn{1}{c}{ Merit } & Demerit \\
\hline $\begin{array}{l}\text { Immobili-zation } \\
\text { with binder }\end{array}$ & Powder & $\begin{array}{l}\text { Paint, paper, nonwoven } \\
\text { fabric, fluorocarbon } \\
\text { sheet, hardened cement }\end{array}$ & $\begin{array}{l}\text { Thick films can be prepared ea- } \\
\text { sily }\end{array}$ & $\begin{array}{l}\text { Loss of activity due to bin- } \\
\text { der, powder dropout, } \\
\text { degradation of binder }\end{array}$ \\
\hline Surface oxidation & $\begin{array}{l}\text { Metallic titanium, } \\
\text { titanium alloy }\end{array}$ & $\begin{array}{l}\mathrm{TiO}_{2} \text { electrode (heat in } \\
\text { the air), building materi- } \\
\text { al (anodic oxidation) }\end{array}$ & Dense films on metal substrate & Smaller specific surface area \\
\hline Coating & $\begin{array}{l}\text { Organic titanium } \\
\text { compounds, } \mathrm{TiO}_{2}\end{array}$ & $\begin{array}{l}\text { Sheet glass, glassware, } \\
\text { ceramics, metal, plastic }\end{array}$ & $\begin{array}{l}\text { Transparent films can be pre- } \\
\text { pared. Surface area increased } \\
\text { by mixing template compounds }\end{array}$ & $\begin{array}{l}\text { Calcination usually at high } \\
\text { temperature (400-600 }\end{array}$ \\
\hline $\begin{array}{l}\text { Sacuum el }) \\
\text { tion, sputtering }\end{array}$ & $\begin{array}{l}\mathrm{Metallic} \mathrm{titanium,}^{\circ} \\
\mathrm{TiO}_{2}\end{array}$ & Sheet glass, etc. & $\begin{array}{l}\text { Precise control of thickness, } \\
\text { composition, etc. }\end{array}$ & $\begin{array}{l}\text { Generally lower activity/ } \\
\text { surface area, higher cost }\end{array}$ \\
\hline
\end{tabular}

ためである.

基本的な材料化の方法を Table 1 に示す. 光触媒 材料は抗菌・防污・防曇用途と, 水質污濁物質や脱 臭を含む空気污染物質分解用途に大別でき，それに 応じて最適の設計を行う必要がある，前者ではもと もと污れなどが付着し難いように, 平滑で緻密な膜 が好まれる，污れの蓄積速度は一般に遅いので, 光 触媒能力はかならずしも高くなくてょく, 光の干渉 色が出ないよう，一般には $0.1 \mu \mathrm{m}$ 程度以下の薄膜 とすることが多い. チタン化合物の溶液を用いた透 明薄膜形成技術は著しい進歩を遂げ，現在ではプラ スチックのような有機物にも, シリカやアパタイト といった保護層を挟んで成膜できるようになってい る.アパタイトで酸化チタン粒子を部分的に被覆す るとともに，その吸着作用を利用することも行われ ている.

これに対し，污染物質分解用途では，より多くの 物質を処理する必要がある. 光が当たる面積は限ら れていることから，多孔質にして深さ方向の厚みを 利用しなければならない。これまでの研究で，1） 比表面積の大きな酸化チタンの使用, 2) 厚い光触 媒膜と多孔質化，3）酸化于タン含有量の拡大など の有効性が確認されている. ${ }^{2)}$

\section{2-3. 光触媒材料の利用方法 光触媒の特徵} は, 浄化したい環境にそのまま置くだけで機能させ 得るということである. セルフクリーニング(防污) 機能は既存の建材等の表面に光触媒をコーティング するだけで獲得できる，抗菌作用も同様である．空 気浄化においても，遮音壁などに設置するだけで沿 道の空気を浄化できる. 人為的なエネルギーを供給 せずに有益な仕事をさせるという意味で，パッシブ

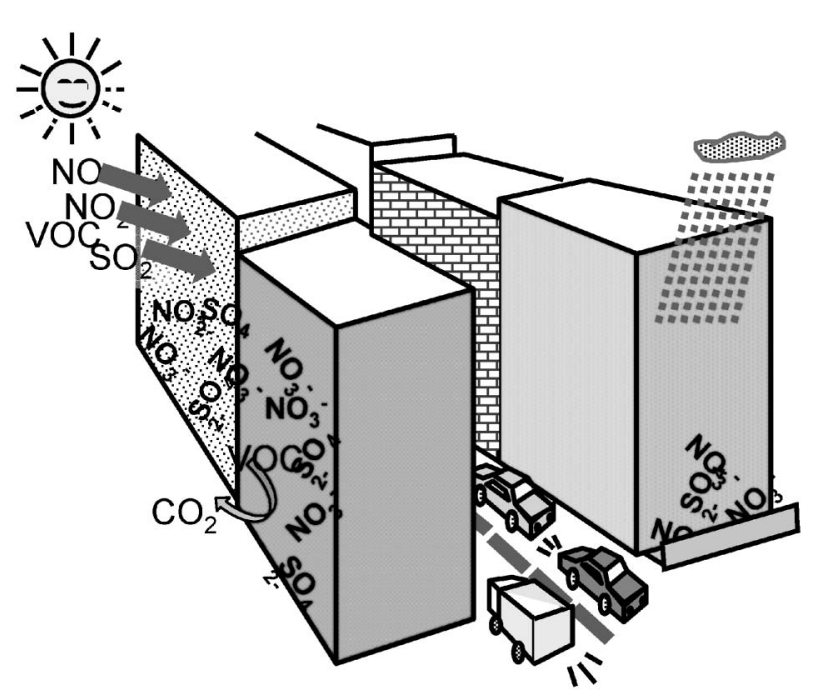

Fig. 2. An Application of Passive Photocatalytic System

システムと呼ばれる（Fig. 2)，光触媒ならではの 新規用途が期待できるが, 反面, その性能は使用環 境に依存するというデメリットがある，例えば，屋 外では遮音壁等に接触した空気だけしか処理されな いし, 日向や日陰もある. 室内でも日中の空際とそ うでないところでは紫外線量が何桁も異なり，どの ような条件で性能評価を行うべきかが議論になると ともに，製造会社ではその性能を保証できないこと になる。最近では通信分野などにおいて，「ベスト エフォート型」の性能表記も行われており，パッシ ブシステムについても参考にできると考えられる.

一方, 空気や水の浄化では, 従来型の浄化装置も 可能であり, こちらは紫外線ランプや送風機が必要 なので，上記のパッシブシステムに対して，アクテ イブシステムと呼ばれる。被処理流体との接触効率 や光触媒材料表面の紫外線照度等を考慮した設計が 
可能であり, 污染物質除去率が $90 \%$ 超える空気 浄化装置も容易に得られる。しかしながら, ユー ザーとしては性能がすべてである場合が多く，コス トやエネルギー効率について既存の他方式との競合 になる。

光触媒の機能は一般に光がなければ停止する。こ のため, 污染物質処理では吸着剤を混合したり, 抗 菌用途では銀イオン等の抗菌剂を加えたりすること があり，これらはハイブリッド光触媒と呼ばれる. アクティブシステムにおいても, 光触媒の能力を高 める薬剤 (過酸化水素，オゾンなど)を添加したり， 超音波や低温プラズマなど他の技術を併用すること がある，異なる機能の組み合せもあり，例えば，光 触媒フィルターの前段に電気集塵器を置いて, カビ 胞子や花粉のようなバイオエアロゾルを捕捉する空 気清浄機がある.

2-4. 普及のための環境整備社ルフクリーニ ング機能といえども, 光触媒の機能はにわかには確 認できない場合が多い。 カタログ等における性能表 示も不統一で, 能力の不十分なものが市場に出まわ るなど消費者の利益を損ねる状況もあった。このた め, 経済産業省は基礎となる材料の試験方法の日本 工業規格（JIS）を制定すべく，2002 年に社日本フ アインセラミックス協会に光触媒標準化委員会を設 置した. Table 2 に示すように，約 5 年間の活動を 経て，このほどJIS 規格全 11 件の制定が完了し た. 引き続き, ISO 提案に取り組んでいる. 光触媒 技術は欧州でも次第に注目を集めてきており，簡単
にはことが進まなくなってきたが，早期の ISO 規 格発行に注力している.

製品については，業界団体である光触媒工業会が JIS/ISO 規格を基礎として, 製品表示ガイドライ ン, 性能基準，認証マーク制度などを設定しつつあ り，真に役に立つ新技術が供給されようとしている.

\section{3. 化学剤について}

3-1. 化学剤の種類 · 特徵 - 致死量 - 化学構造 化学剂は人体に対する作用により神経ガス（神経 伝達を錯乱)，びらん剂（皮膚などの接触面をびら ん), 血液剂(細胞による酸素呼吸を阻害), 窒息剤 (呼吸器系統に障害), 催吐剂 (呼吸器系統や眼の粘 膜を刺激), 催涙剂 (眼, 鼻, 咽頭粘膜を刺激), 無 力化剂（身体的及び精神的に活動を抑制）があ

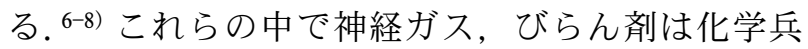
器以外に使用目的はない. 代表的な化学剂の化学構 造, 蒸気圧, 揮発性及び半数致死暴露量 $\left(\mathrm{LCt}_{50}\right)$ を Table 3 に示す. ${ }^{6-8)}$

神経ガスには， $\mathrm{G}$ 剤であるサリン $(\mathrm{GB})$, ソマン (GD)，タブン（GA）やV 剂と呼ばれるVXガス が指定されている。神経ガスの揮発性は比較的低い が, 半数致死暴露量, $\mathrm{LCt}_{50}$, が 10-400 と他の化学 剂と比較して毒性が非常に強く, 人体がこれらの化 学剤に暴露された場合の致死率は高い。G 剂は主 に吸入により作用するが，V 剂である VXガスは皮 膚から体内に浸入し作用する。いずれの化学剤も人 体に対して早く作用する。これら神経ガスは，リン を骨格とした化学構造を持ち, $\mathrm{F}, \mathrm{CN}$ 及び $\mathrm{SCH}_{2}$

Table 2. Summary of Standardization for Testing Photocatalytic Materials

\begin{tabular}{llccccc}
\hline \hline \multicolumn{1}{c}{ Group } & \multicolumn{1}{c}{ Test method } & JIS proposal & JIS enacted & JIS No. & ISO proposal & ISO No. \\
\hline \multirow{2}{*}{ Self-cleaning } & $\mathrm{H}_{2}$ O contact angle & $2006 / 03$ & $2007 / 07$ & $\mathrm{R} \mathrm{1703-1}$ & 2005 & CD 27448-1 \\
& Methylene blue & $2006 / 03$ & $2007 / 07$ & $\mathrm{R} \mathrm{1703-2}$ & 2006 & WD 10678 \\
\hline \multirow{2}{*}{ Air } & Nitric oxide & $2003 / 03$ & $2004 / 01$ & $\mathrm{R} \mathrm{1701-1}$ & 2003 & ISO 22197-1 \\
& Acetaldehyde & $2006 / 03$ & $2008 / 03$ & $\mathrm{R} \mathrm{1701-2}$ & 2006 & WD 22197-2 \\
& Toluene & $2006 / 03$ & $2008 / 03$ & $\mathrm{R} \mathrm{1701-3}$ & 2006 & WD 22197-3 \\
& Formaldehyde & $2007 / 03$ & $2008 / 10$ & $\mathrm{R} \mathrm{1701-4}$ & 2008 & to propose \\
& Methylmercaptan & $2007 / 03$ & $2008 / 10$ & $\mathrm{R} \mathrm{1701-5}$ & 2008 & to propose \\
\hline \multirow{2}{*}{ Water } & Dimethylsulfoxide & $2006 / 03$ & $2007 / 10$ & $\mathrm{R} \mathrm{1704}$ & 2006 & WD 10676 \\
\hline \multirow{2}{*}{ Bacteria fungi } & Antibacterial & $2006 / 03$ & $2006 / 09$ & $\mathrm{R} \mathrm{1702}$ & 2005 & CD 27447 \\
& Antifungal & $2007 / 03$ & $2008 / 03$ & $\mathrm{R} \mathrm{1705}$ & 2008 & to propose \\
\hline \multirow{2}{*}{ Light } & Light source & $2006 / 03$ & $2007 / 07$ & $\mathrm{R} \mathrm{1709}$ & 2006 & WD 10677 \\
\hline
\end{tabular}

Items in Italics are not completed yet. 
Table 3. Properties of Chemical Warfare Agents

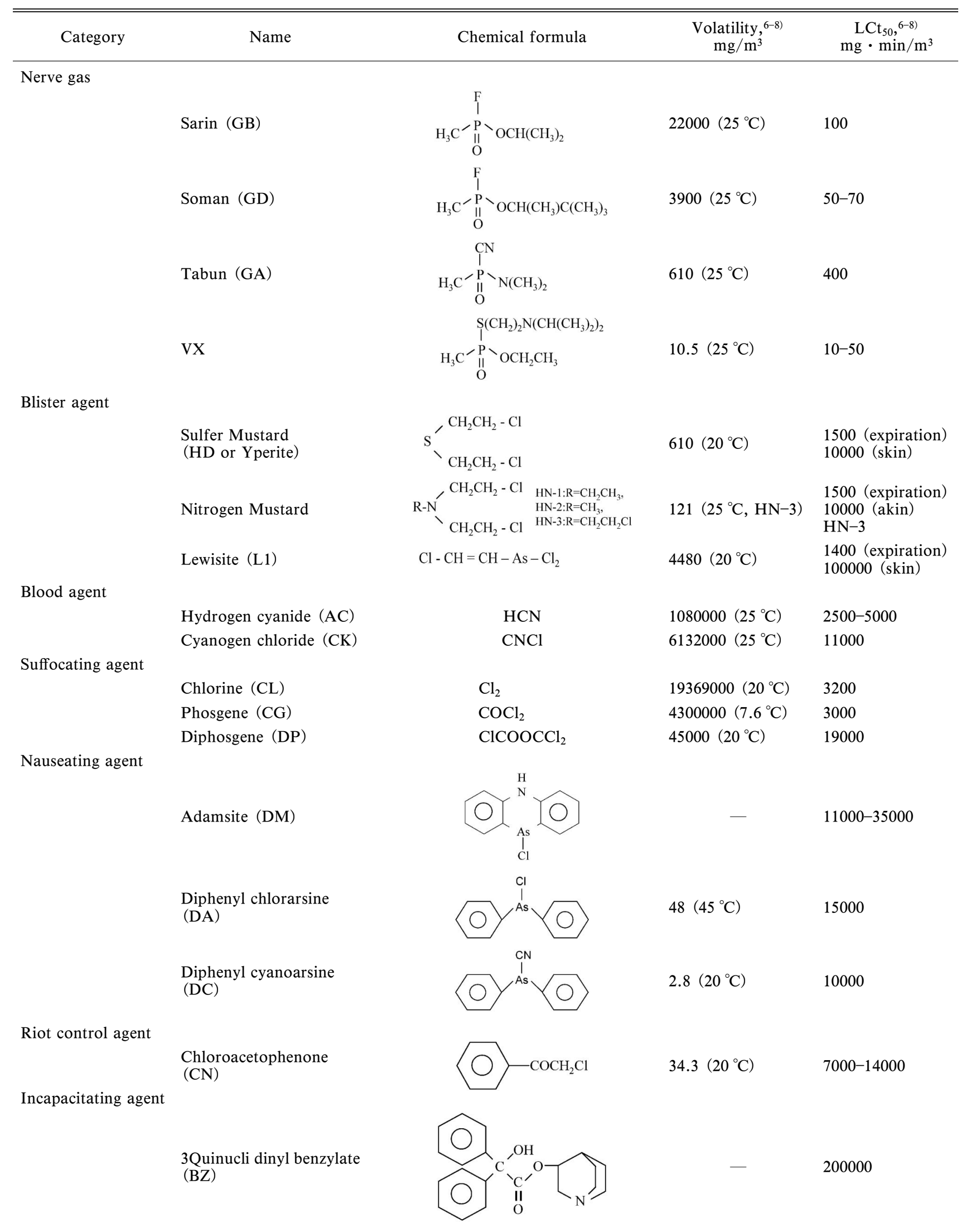


$\mathrm{CH}_{2} \mathrm{~N}\left(\mathrm{CH}\left(\mathrm{CH}_{3}\right)_{2}\right)_{2}$ 基が神経伝達の働きをするアセ チルコリンエステラーゼと強く結合してその働きを 低下させる。これにより筋肉は興奮状態が治まらな くなり，痤攣などを起こし重度の場合には死に至 る. したがって，化学兵器に使用される化学剤の中 で最も殺傷能力が高いとされる，特にVX は持久性 に優れ効果は数週間から数力月に渡り持続する.

びらん剤としては，代表的なものに硫黄マスター ドガス（HD，イペリットとも呼ばれる）や窒素マ スタード（HN）がある。また構造にヒ素（As）を 元素として含む，ルイサイト (L1)，エチルジクロ ロアルシン $(\mathrm{ED})$, フェニルジクロロアルシン （PD）も合成されている，いずれも皮膚をびらんさ せ，L1，ED，PD はひ素中毒症状を併発させる。 HD 及び L 1 は，呼気吸入による $\mathrm{LCt}_{50}$ が 1500 , 及 び 1400 , 皮膚接触の場合には 10000 及び 100000 と 毒性は神経ガスに比べ低下する．HD や NH-3 など は作用するまで 4-6 時間の時間を必要とするが L1 は早く作用する。これらびらん剂の人体への作用機 構は明確ではないが，皮膚内部の真皮に浸透し DNA を直接破壊して細胞死（アポトーシス）の状 態を誘発し，この状態に体が抵抗することで発赤や 水泡等の火傷のような症状を誘発すると考えられて いる．持久性に優れ HD は 1-2 日， NH-3 は HD よ りも寿命は長い。

血液剂は，青酸ガスで知られるシアン化水素 (AC)，塩化シアン（CK）が知られており，いずれ も揮発性が高く, 室温では気体として存在する. $\mathrm{LCt}_{50}$ が 2500-5000（AC）及び $11000(\mathrm{CK})$ と殺傷 能力は他の化学剂に比べ低下するが, 高濃度のガス に人体が暴露されることで中毒を発症し死に至る猛 毒である。いずれの化学剂も人体に対して早く作用 し，致死量の $\mathrm{AC}$ に暴露された場合には 1-2 分で動 けなくなり 15 分以内に死亡する. いずれも肺から 血液に浸入しチトクロームオキシターゼと結合して 細胞の呼吸を抑止することで，アポトーシスを誘発 する。これにより酸素分子を保持したへモグロビン が血管中に残留して静脈が赤くなるのに加え，粘膜 等を刺激して痛みを引き起こしたりもする.ガスで あるため，污染現場におけるガス污染の持続性はな い.

窒息浏には塩素ガス（CL）やホスゲン $(\mathrm{CG})$, ジホスゲン（DP）が知られており，揮発性が高く
常温では気体であり，容易に分散する。CL の $\mathrm{LCt}_{50}$ は 3200, CG は 3000，DP は 45000 であり神 経ガスに比べると毒性は低いが，高濃度に人体が暴 露されることで, 肺水腫等を引き起こし呼吸困難に なるなど，呼吸器系組織を破壊し死に至る毒ガスで ある．空気の流れのあるところでは効果は瞬時に消 えるが，風がない場合には低いところに停滞する。 DP の場合は，夏は 30 分から 3 時間，冬は 10-12 時間残存する.

催吐剤として代表的なものはアダムサイト（DM） やジフェニルクロロアルシン（DA），ジフェニル シアノアルシン（DC）が知られており，ヒ素を元 素として含む．いずれも揮発性は低く, $\mathrm{LCt}_{50}$ は DM で 11000-35000，DA，DCでは 15000，10000 と 殺傷能力は低い。いずれの化学剂も人体に対して早 く作用し，呼吸により人体内部に取り込まれること で，嘔吐を引き起こす，持久性はなく，速やかに分 解される.

催涙剤は種類が多く，代表的な化合物としてクロ ロアセトフェノン $(\mathrm{CN})$ が知られている. 高沸点 の化合物であり揮発性はほとんどなく, $\mathrm{LCt}_{50}$ は 7000〜14000 と殺傷能力は低いが，作用を発現させ る濃度は $1.5 \mathrm{mg} \mathrm{min} / \mathrm{m}^{3}$ と低く即効性を有する。主 に眼に作用して，皮膚に一時的な刺激を与える．催 涙剂の化学構造から遺伝子に影響することが指摘さ れているが，詳細は不明である。

無力化剂は，化合物として種類は多いとされてい るが，構造を含めた詳細な情報の公開が少ないため 列挙できないが，3-キヌクロジニルベンジラート （BZ）が知られている．アトロピンに類似した作用 を有するが毒性は BZ の方が 3 倍程度高い。体内に 吸収されると神経系統に作用して幻覚を生じさせ る。使用する濃度によっては強い殺傷能力を発揮す る.

上記の化学剂の詳細な特性や, 他の化学剂に関す る特性に関しては，優れたテキストがあるのでそち らを参照されたい. ${ }^{6-8)}$ 本稿では, 殺傷能力の高い 神経ガス及びびらん剂に着目して，これまでの除染 方法及び光触媒による分解と除染に関する研究につ いて簡単に紹介する.

\section{3-2. 化学剤の除染方法}

3-2-1. 液体による除染方法 化学兵器が地域 環境において使用された場合に行われる除染方法と 
しては，応急除染，乾的除染，水的除染が挙げられ る。それらの中で，どの方法を適用するのかは，污 染の規模や場所，状況によって異なる. ${ }^{6-8)}$

污染が比較的小規模な場合は応急除染が適用で き，污染物を撤去すればよい。また，人体暴露によ つて着衣が污染された程度であれば脱衣などを行う 乾的除染でも十分である.

污染規模が大きい，又は化学剤が特定できない場 合は，水的除染を行うのが主流である，現在までの ところ, 気中に存在する化学剂に対しては, 次亜塩 素酸ナトリウムなどの酸化剂やアルカリ塩を含んだ 水溶液や，カルシウム塩や酸化マグネシウム粉末を 添加した除染液を噴霧して除染し，周辺物質に吸着 した化学剂に対しては，それらの除染液で洗い流す ことにより除染する.

除染液については，その他に銅などの金属イオン や，酸化活性のある酵素を含むものや，過酸化水素 と金属イオンを併用したものも研究されている。 し かしながら，それらの溶液は溶媒の種類， $\mathrm{pH}$ ，温 度などに影響されることや，特に酵素による除染 は，安全性や化学的な機構が複雑過ぎることから， 緊急的な使用には適さないようである.

また，除染液の使用にはいくつかの問題点もあ り，溶液のアルカリ性が低下するのを避けるため除 染直前に除染液を調整しなければならないことや， 周辺にあるものを酸化剤やアルカリにより腐食させ られるなど，除染後の周辺地域環境の 2 次污染の問 題があった。これらについては，緩衝溶液を利用す
ることや，化学的に安定なアルカリとして機能する 化合物を使用することで解決されている。 一方で未 解決の問題もあり，それは使用後の除染液の回収で ある。完全に除染するためには大量の除染液が必要 とされる。例として，地下鉄サリン事件ではアルカ リ性水溶液が除染液として使用され，数トン単位の 污染水が回収された。使用済夕除染液の回収が不十 分な場合，除染剤そのものによる二次污染により除 染現場の復旧に多大な影響を与える。したがって除 染後には，除染液を洗い流し，その廃液を回収し て，さらにその廃液を適切に処理する必要がある。

以上のことから，除染現場で化学剂を回収し，無 毒化することができ，除染作業後の二次污染源にな らず，後処理が不要，又は簡略化が可能な除染方法 の開発が望まれる。

上記除染方法が適用できない IT 機器が設置され た環境での除染方法として，近年では熱風により機 器内部の化学剂を追い出す風乾除染という方法も考 案されている.この方法も含めた 4 つの除染方法を Fig. 3 にまとめて示す。また除染液中の化学剤の無 毒化に関しては詳しく研究されており，いくつかま とめられたものが報告されているので参照された い. ${ }^{6-12)}$

\section{3-2-2. 固体酸化物による吸着除染固体酸化} 物粉末を使用した除染手法も長い間研究されてい る。応急除染に含まれる活性白色土のように固体酸 化物の粉末が使用される場合，化学剂は固体酸化物 表面に吸着する．化学剤が酸化物表面に吸着するこ

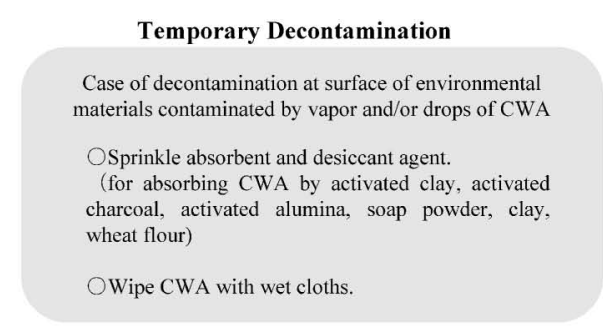

Dry Decontamination

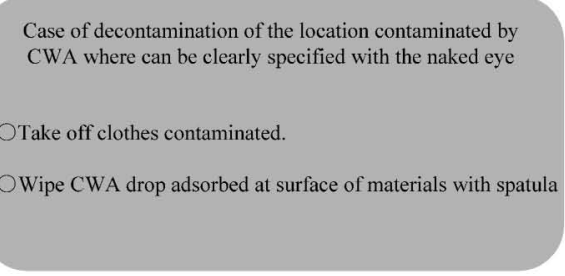

\section{Water Decontamination}

Case of decontamination of unclear CWA and the properties such as liquid, vapor and splash

Wash off unclear CWA by spray with vapor or liquid of alkaline solution, hypochlorous acid, hydrogen peroxide solution, soapsuds and buffer solution.

\section{Hot blast Decontamination}

Case of decontamination of the location contaminated by CWA where can not use any powder and solution, and can not be wiped by wet clothes.

(inside PC, air plane control, PC station, etc.. )

Exhaust an inside computer, $\mathrm{PC}$ station. air plane control of CWA drops and vapor with hot blast that was adjusted to be suitable temperature.

(role of hot blast: drying and exhausting.)

Fig. 3. Chemical Warfare Agent Contamination and Decontamination Method 
とで，化学剂は分解され無毒な化合物になることが 確認されている. ${ }^{13-18)}$

例えば， $\mathrm{GB}$ は $\mathrm{Al}_{2} \mathrm{O}_{3}$ や $\mathrm{MgO}$ の表面に吸着する ことで加水分解されて毒性を失うことが 1976 年に 報告されている. ${ }^{13)}$ Figure 4 に示したように，GB のホスホリル基 $\left(\mathrm{O}=\mathrm{P}\right.$ 基）が $\mathrm{Al}_{2} \mathrm{O}_{3}$ 酸化物表面の Lewis 酸点である $\mathrm{Al}$ 原子上に吸着し，その周辺に 存在する表面水酸基が GB の $\mathrm{P}$ に求核攻撃するこ とで加水分解が進行する．結果として酸化物表面に Al-F とリン酸化合物 (adsorbed methyl isopropylphosphonate: MIPPad) が吸着した形で生成する.

これと同様に，VX，GD，GB，HD の化学剂を, 酸 化物である $\mathrm{MgO}, \mathrm{CaO}, \mathrm{Al}_{2} \mathrm{O}_{3}, \mathrm{TiO}_{2}$ に吸着させるこ とで加水分解を行い，化学剂を無毒にする研究が 1999 年から 2007 年にかけて精力的に行われてい る. ${ }^{15-18)}$ 化学剤がこれら酸化物表面に吸着すること で，毒活性を示す $\mathrm{F}$ や $\mathrm{SCH}_{2} \mathrm{CH}_{2} \mathrm{~N}\left[\mathrm{OCH}\left(\mathrm{CH}_{3}\right)_{2}\right]_{2}$ 基が化学剤から加水分解され無毒化されることが報 告されている.しかしながらその処理量は酸化物の 表面積により制限される，HDの分解過程は，酸化 物表面及び周辺に共存する水分量により異なり，水
分量が多いと $\mathrm{HCl}$ が多量に生成して $\mathrm{CaO}$ 及び $\mathrm{Al}_{2}$ $\mathrm{O}_{3}$ の酸化物表面を融解させ, $\mathrm{CaCl}_{2}$ 塩などを生成 するようだが，溶解による塩の形成は化学剤の無毒 化を促進させると報告されている（Fig. 5).

$\mathrm{G}$ 剂， $\mathrm{V}$ 剂，HD などの化学剂は，固体表面に接 触するだけで無毒化され, 特に HD は水分が適度 に調整されることで効果的に無毒化・分解される. しかしながら，固体表面には化学剤よりは毒性は低 下するが，有毒であるリン酸化合物や硫黄化合物な ぞが残留する．また，いずれの化学剂に対しても確 実な除染を達成するには，十分量の粉末を用いる必 要がある。

\section{4. 光触媒反応による化学剤の分解の研究}

4-1. 光触媒を用いた研究酸化物として光に 応答して酸化還元反応を進行する酸化物半導体光触 媒を用いることで, 吸着した化学剂を光により完全 に分解することが期待される。すなわち，化学剤の 分解は表面積により制限されないのに加え, Fig. 4 及び 5 に示したような有機化合物の残留も解消され る. また, 処理後に廃液を大量に生じさせる除染液 の噴霧という工程を取る必要がなくなる。しかしな

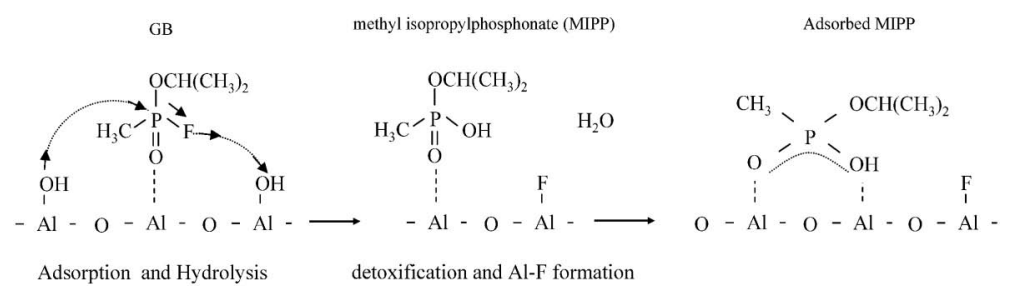

Fig. 4. Detoxification Process with Hydrolysis of GB on $\gamma-\mathrm{Al}_{2} \mathrm{O}_{3}$ Powder

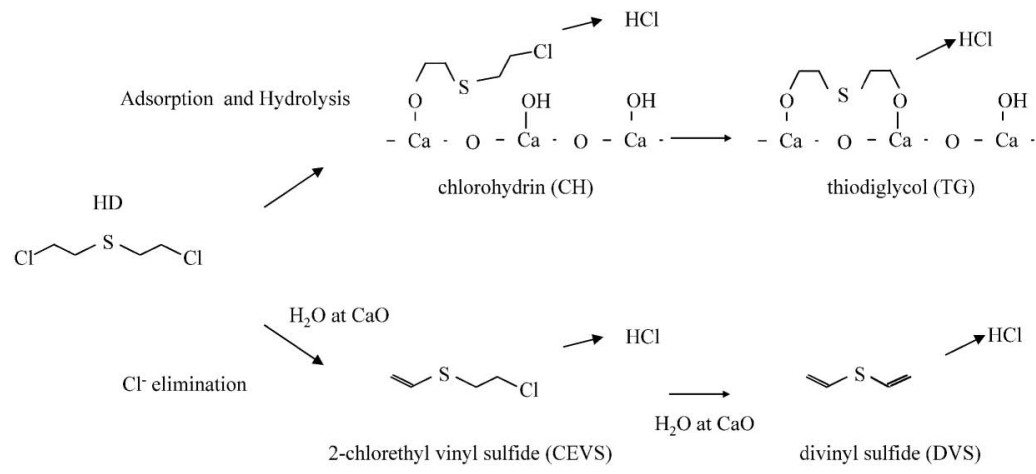

$2 \mathrm{HCl}+\mathrm{CaO} \rightarrow \mathrm{CaCl}_{2}+\mathrm{H}_{2} \mathrm{O} \longrightarrow \mathrm{CaCl}_{2}+\mathrm{HD} \rightarrow$ hydrolysis $+\mathrm{Cl}^{-}$elimination

Fig. 5. Detoxification Process with Hydrolysis of $\mathrm{HD}$ on $\mathrm{CaO}$ Powder 
がら，化学剂を使用するのは非常に危険であるのに 加え，製造，使用に制限があるために，実際に化学 剂を使用した研究例は非常に少ない。例えば，1989 年に HD を光触媒により分解したという報告は, 試験はアセトニトリル溶媒中で行われており詳細は 不明である. ${ }^{19)}$ 近年になり $\mathrm{GB}, \mathrm{GD}, \mathrm{HD}$ を $\mathrm{TiO}_{2}$ 光 触媒反応により分解させる研究内容が Cheng らの グループにより報告されている。 ${ }^{20)}$ Cheng らのグ ループは，光触媒反応により $\mathrm{GB}$ が分解され $\mathrm{CO}_{2}$ が生成することを報告した。しかしながら，この研 究グループは $254 \mathrm{~nm}$ の光により $\mathrm{GB}$ を直接分解す る photolysisに関する研究を中心に行っており，

$\mathrm{TiO}_{2}$ 表面上への化学剤の吸着過程や, 光触媒反応

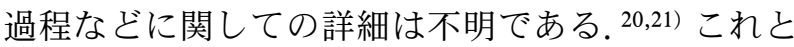
は反対に, 化学剂と構造が類似している擬似化学剂 を使用した光触媒反応の研究報告内容が有力な知見 を以下に示すように提供している。

4-2. HD 1983 年に Davidson と Pratt らは, 大気開放下のアセトニトリル溶媒中に溶解した di$n$-butylsuphide（DBS）など, HD 類似構造を有す る 5 種類の硫黄化合物をアナターゼ型の $\mathrm{TiO}_{2}$ を用 いて, 光触媒反応により分解する研究を行った. ${ }^{22)}$ Figure 6 に擬似化学剂を使用した光触媒の研究の歴 史を示したが，DBS を用いた研究が擬似化学剂を 光触媒で分解した最初の研究であることが分かる. その後, Fox らは，アセトニトリルに溶解させたチ オエーテル化合物, $\mathrm{S}\left(\mathrm{CH}_{2}-\mathrm{Ph}-\mathrm{X}\right)_{2}: \mathrm{X}=\mathrm{OCH}_{3}$, $\mathrm{CH}_{3}, \mathrm{H}, \mathrm{Cl}, \mathrm{Br}$ ，を光触媒反応により分解する研究 結果を報告している. ${ }^{23)}$ 当時の研究では, アセトニ トリル溶媒中で光触媒反応が行なわれており, 硫黄 化合物が $\mathrm{TiO}_{2}$ 光触媒反応により分解されることが 確認されている. ${ }^{23,24)}$ 近年までに，HDの擬似化学 剤としては，化学構造が酷似しているジメチルスル フィド (DMS)，ジエチルスルフィド (DES) ${ }^{25-27)}$ 及び 2-chloroethyl ethyl sulfide (2CEES) 28-34) が用い られるようになり, 光触媒による化学剂の分解に関 する研究が盛んに行われるようになった。 そこで, 本稿では，研究報告例が多く，分解機構が明瞭にな つている DES 及び 2CEES について解説する．Table 4 に DES 及び 2CEES の化学構造を示した.

$\mathrm{DES}$ を $\mathrm{TiO}_{2}$ 光触媒により分解する研究は, Smirniotis らのグループにより行われ 2001 年に結 果が報告されている. ${ }^{25)}$ 気中に気化された DES を

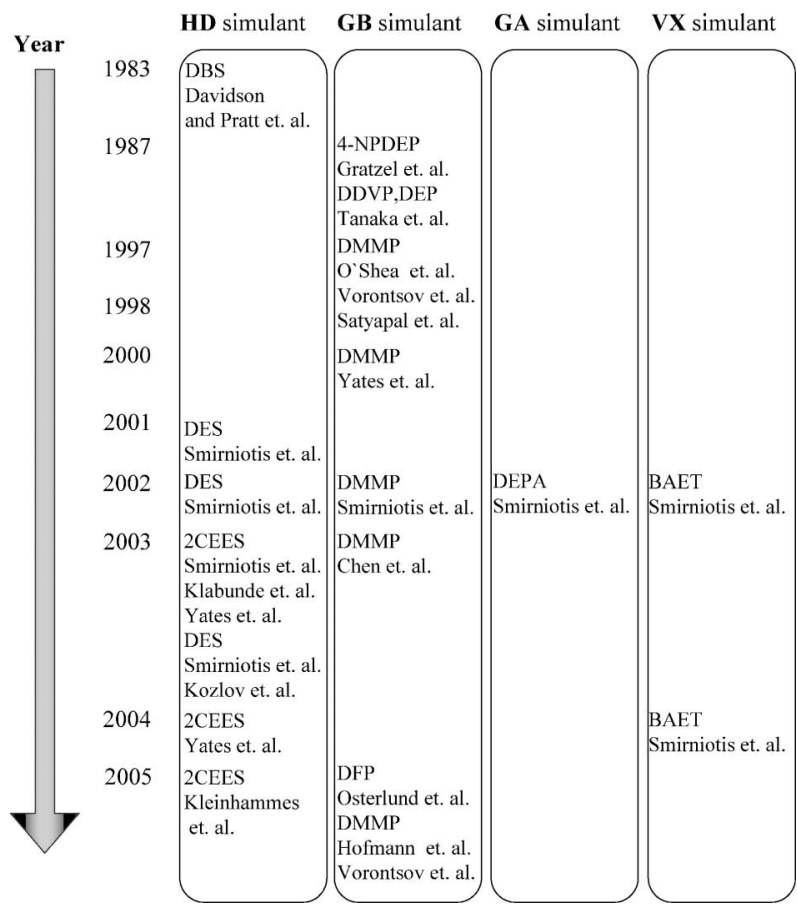

Fig. 6. Progress in the Study for Decomposition of CWA Use $\mathrm{TiO}_{2}$ Photocatalysis

Table 4. Chemical Structure of CWA Simulant Compounds

\begin{tabular}{|c|c|c|c|}
\hline Category & $\begin{array}{l}\text { CWA } \\
\text { name }\end{array}$ & $\begin{array}{l}\text { Simulant } \\
\text { compound }\end{array}$ & Simulant formula \\
\hline \multicolumn{4}{|l|}{$\mathrm{G}$ agent } \\
\hline & GB, GD & $\begin{array}{l}\text { Dimethyl } \\
\text { Methyl- } \\
\text { phosphonate } \\
\text { (DMMP) }\end{array}$ & $\mathrm{H}_{3} \mathrm{C}_{\substack{\mathrm{O} \\
\mathrm{O}}}^{\mathrm{P}} \backslash \mathrm{OCH}_{3}$ \\
\hline & GB, GD & $\begin{array}{l}\text { Diisopropyl } \\
\text { fluoro- } \\
\text { phosphonate } \\
\text { (DFP) }\end{array}$ & 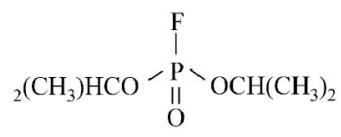 \\
\hline & GA & $\begin{array}{l}\text { Diethyl Phos- } \\
\text { phoramidate } \\
\text { (DEPA) }\end{array}$ & 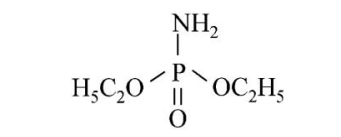 \\
\hline \multicolumn{4}{|l|}{$\mathrm{V}$ agent } \\
\hline & vX & $\begin{array}{l}\text { 2-(butylamino) } \\
\text { ethanethiol } \\
\text { (BAET) }\end{array}$ & $\mathrm{HS}\left(\mathrm{CH}_{2}\right)_{2} \mathrm{NH}\left(\mathrm{CH}_{2}\right)_{3} \mathrm{CH}_{3}$ \\
\hline \multicolumn{4}{|c|}{ Blister agent } \\
\hline & $\begin{array}{l}\text { sulfer } \\
\text { mustard }\end{array}$ & $\begin{array}{l}\text { diethyl sulfide } \\
\text { (DES) }\end{array}$ & $\mathrm{S}^{\prime} \mathrm{CH}_{2} \mathrm{CH}_{3}$ \\
\hline & $\begin{array}{l}\text { sulfer } \\
\text { mustard }\end{array}$ & $\begin{array}{l}\text { 2-chloroethyl } \\
\text { ethyl sulfide } \\
\text { (CEES) }\end{array}$ & $\begin{array}{l}\mathrm{s}^{\prime} \mathrm{CH}_{2} \mathrm{CH}_{3} \\
\mathrm{CH}_{2} \mathrm{CH}_{2}-\mathrm{Cl}\end{array}$ \\
\hline
\end{tabular}

連続的にフローさせ, $\mathrm{TiO}_{2}$ 光触媒により分解を行 い，その分解機構及び活性に対する湿度依存性につ いて調査している。低湿度（<1\%）におけるDES 
に対する光触媒の分解活性が，湿度 $59 \%$ の場合に 対して 1.6 倍程度高いことを見い出した。この理由 として, 高湿度では光触媒表面上の水分量が増加 し，それによりDES の吸着量が低下するためであ ると提案している。湿度により生成される中間体化 合物の種類に違いはなく，気中においては主にエ夕 ノール (EtOH)，アセトアルデヒド $\left(\mathrm{Ac}: \mathrm{CH}_{3} \mathrm{CHO}\right)$, エチレン $\left(\mathrm{C}_{2} \mathrm{H}_{4}\right)$ ，が生成され，ほかにジエチルジス ルフィド (DEDS: $\mathrm{CH}_{3} \mathrm{CH}_{2} \mathrm{~S}_{2} \mathrm{CH}_{2} \mathrm{CH}_{3}$ ), diethyl trisulfide (DETS: $\mathrm{CH}_{3} \mathrm{CH}_{2} \mathrm{~S}_{3} \mathrm{CH}_{2} \mathrm{CH}_{3}$ ), S-ethyl ethanthionate (SEET: $\mathrm{CH}_{3} \mathrm{CH}_{2} \mathrm{SCOCH}_{3}$ ), hydroxyethyl ethyl sulfide (HEES: $\mathrm{CH}_{3} \mathrm{CH}_{2} \mathrm{SCH}_{2} \mathrm{CH}_{2} \mathrm{OH}$ ), 酢酸 $(\mathrm{AC}), \mathrm{SO}_{4}^{2-}, \mathrm{CO}_{2}$ が検出されている。触媒表面上 からは DEDS, HEES, diethyl sulfoxide (DESO: $\mathrm{CH}_{3}$ $\left.\mathrm{CH}_{2} \mathrm{SOCH}_{2} \mathrm{CH}_{3}\right)$ が検出されている.

同グループは，フロー状態にある気化 DES を $\mathrm{TiO}_{2}$ 光触媒反応により連続的に分解するためのシ ステムを試験的に構築し，2003 年に研究内容を報 告している. ${ }^{26)}$ 気中拡散された $\mathrm{DES}$ は, $\mathrm{TiO}_{2}$ 光触 媒反応より連続的に分解されるが，反応が進行する のに伴い光触媒表面上に DEDS, DESO, HEES が 蓄積され光触媒が不活性化されることを示した。こ の不活性化表面の再生は，清浄な空気流れの下で光 照射を行うだけでは不十分であり，硫酸水溶液によ る洗浄が必要であることを見い出した.

2003 年に Kozlov と Smirniotis らのグループは,
光触媒反応による DES 分解過程と不活性化メカニ ズムの関係について，閉鎖系にて試験することで明 らかにしている. ${ }^{27)}$ 濃度既知の気化 DES の分解を 繰り返すことで，光触媒表面上の $\mathrm{Ti}$ サイト上に硫 酸塩及び炭酸塩が形成されることを拡散反射 IR （DRS）測定から明らかにした。 DES が分解される ことで生成される $\mathrm{CO}_{2}$ の生成速度が，繰り返し回 数の増加により減速していたことから, 硫酸塩及び 炭酸塩の残留が光触媒活性を低下させる原因である と提案している。 また，この $\mathrm{CO}_{2}$ の発生は，気中 の DES がほぼ消滅してから著しく加速されること から，光触媒反応で生成される中間体よりも DES の分解が優先して進行することも見い出した.この 現象は DES のイオン化ポテンシャルが他の中間体 よりも低いことから，優先的に酸化されるためと考 えられている. $\mathrm{TiO}_{2}$ 光触媒反応による $\mathrm{DES}$ の分解 機構は Fig. 7 (a)，（b)にまとめた。

化学構造に $\mathrm{Cl}$ を含む $2 \mathrm{CEES}$ (Table 4) を $\mathrm{TiO}_{2}$ 光触媒により分解する研究内容は, Klabunde らに より 2003 年に報告されている. ${ }^{28)}$ 閉鎖系反応容器 内に気化させた $2 \mathrm{CEES}$ を, $\mathrm{TiO}_{2}$ 光触媒により分解 させ，その分解機構及び光触媒活性の温度依存性に ついて，GCMS 及びFTIR を用いて研究を行って いる，導入した気化 $2 \mathrm{CEES}$ のほとんどが $\mathrm{TiO}_{2}$ 光 触媒表面に吸着され，光触媒反応により完全に分解 された。 EtOH, Ac, $\mathrm{C}_{2} \mathrm{H}_{4}$, DEDS, クロロエチレン

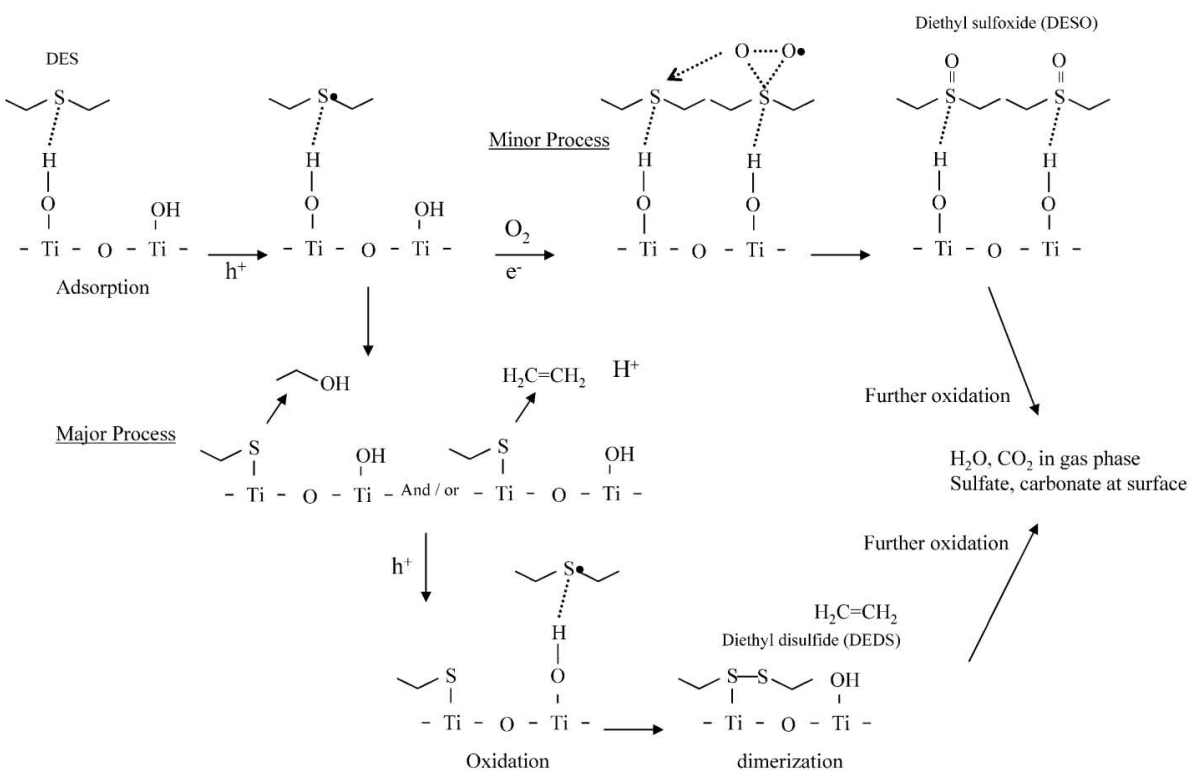

Fig. 7 (a) . $\quad \mathrm{TiO}_{2}$ Photocatalytic Oxidation Mechanism of DES-1 


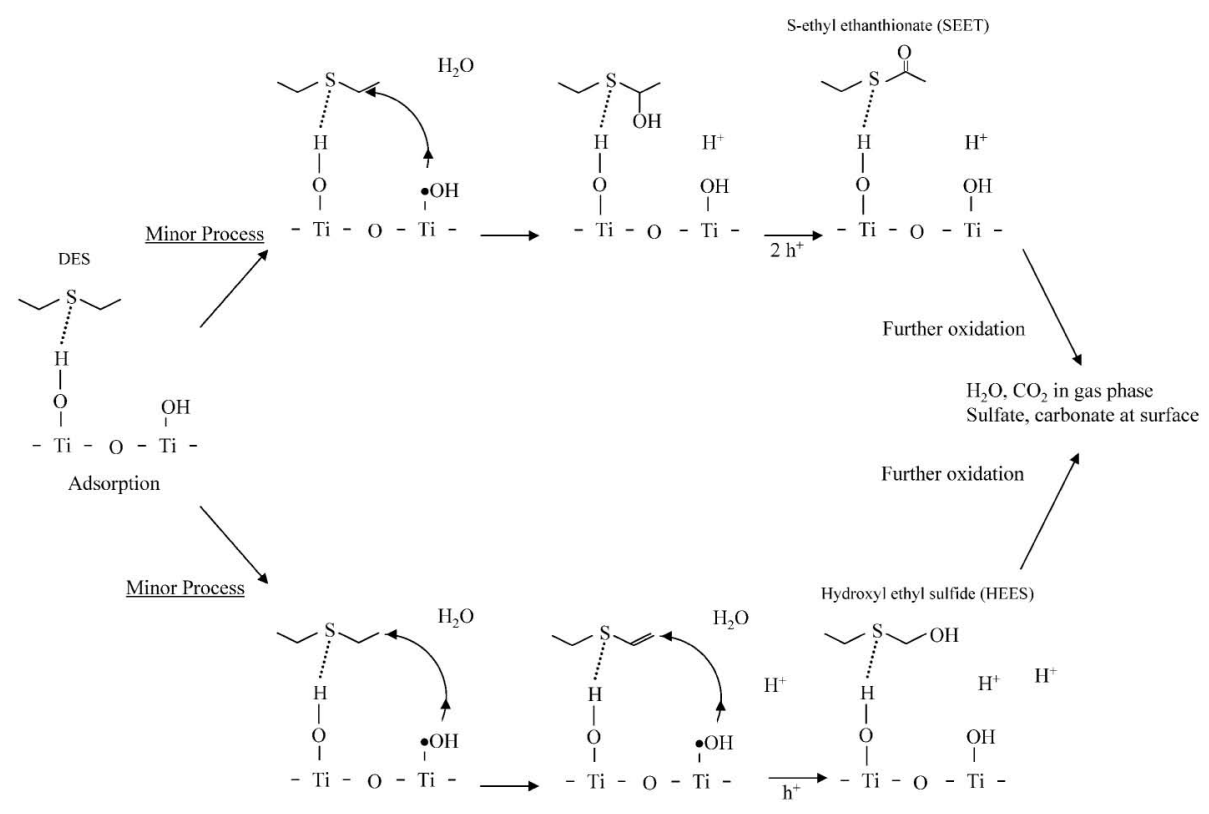

Fig. 7 (b) $\quad \mathrm{TiO}_{2}$ Photocatalytic Oxidation Mechanism of DES-2

$\left(\mathrm{ChE}: \mathrm{ClCHCH}_{2}\right)$ ，クロロアセトアルデヒド (ChAc: $\left.\mathrm{ClCH}_{2} \mathrm{COH}\right)$ が気中で観察され, 光照射の 継続とともにそれらは減少し，最終的に $\mathrm{H}_{2} \mathrm{O}, \mathrm{CO}_{2}$, $\mathrm{SO}_{2} ， \mathrm{SO}_{4}^{2-}$ に分解された．温度を $80{ }^{\circ} \mathrm{C}$ に上げるこ とで, 気中に拡散している EtOH, Ac, ChAc, DEDS の濃度が増加するのに加え，2-クロロエチルエチ ルジスルフィド (2CEEDS: $\mathrm{ClCH}_{2} \mathrm{CH}_{2} \mathrm{SOCH}_{2} \mathrm{CH}_{3}$ ),

bis-（2-クロロエチル）ジスルフィド（b2ChED: $\mathrm{ClCH}_{2} \mathrm{CH}_{2} \mathrm{~S}_{2} \mathrm{CH}_{2} \mathrm{CH}_{2} \mathrm{Cl}$ )， SEET，2-クロロエ夕 ノール (2ChEtOH: $\left.\mathrm{ClH}_{2} \mathrm{CH}_{2} \mathrm{OH}\right)$ ，塩化エタンス ルホニル (ESCh: $\mathrm{CH}_{3} \mathrm{CH}_{2} \mathrm{SO}_{2} \mathrm{Cl}$ ), クロトンアル デヒド ( $\left.\mathrm{CrAc:} \mathrm{CH}_{3} \mathrm{CHCHCOH}\right)$, 酢酸メチル (MA: $\mathrm{CH}_{3} \mathrm{COOCH}_{3}$ ), ぎ酸メチル (MF: $\left.\mathrm{CH}_{3} \mathrm{OCOH}\right)$ が新たに検出された。温度上昇によるこれら新たな 中間体生成物の検出は，低揮発性分子の表面からの 脱離によると考察されている。また，揮発性が著し く低い DEDS, 2CEEDS 及び b2ChED は温度に依 存せずに触媒表面上から検出され， $\mathrm{HCl}$ 及び $\mathrm{SO}_{2}$ については $\mathrm{TiO}_{2}$ 表面上に強く吸着していることが 見い出された. 2CEES は化学構造に $\mathrm{Cl}$ を含むこと から，DES とは異なる種類の中間体の生成が観測 されているが，DES の場合と同様に光触媒が不活 性化される点を問題点として挙げている.

2003 年に Smirniotis らのグループは，フロー状 態にある気化 $2 \mathrm{CEES}$ を $\mathrm{TiO}_{2}$ 光触媒反応により連 続的に分解して，その反応機構について報告してい
る. ${ }^{29)} 2 \mathrm{CEES}$ は $\mathrm{TiO}_{2}$ 光触媒反応により $\mathrm{CO}_{2}, \mathrm{H}_{2} \mathrm{O}$, $\mathrm{SO}_{2}$ に完全に分解されることを GCMS や FTIR か ら解析した。検出された中間体は，Klabude らによ る報告内容とほぼ同じであり，Cl を含む中間体が 生成される以外は，分解機構は同グループが先に報 告した DES の機構 25,26$)$ に類似すると述べている. 新たにエタンスルホン酸（ESA: $\mathrm{CH}_{3} \mathrm{CH}_{2} \mathrm{SO}_{2} \mathrm{H}$ ) が 中間体化合物として観察され，この $\mathrm{ESA}$ は $\mathrm{TiO}_{2}$ 光触媒表面上に強く吸着していることを見い出し た。暗所にて， $2 \mathrm{CEES} \mathrm{が} \mathrm{TiO}_{2}$ 光触媒表面上に吸着 すると, 表面吸着水により加水分解され HEES 及 び極微量の HD を生成することも見い出してい る。検出された HD は極微量であり, 光触媒反応 により分解されるため危険性はないと主張している. 2CEES が光触媒反応により完全に分解されたのち, $\mathrm{TiO}_{2}$ 表面に単座と二座配位硫酸塩が残留している ことが観測されたが，硫酸水溶液を用いて光触媒を 洗浄することで，一座配位硫酸塩が除去されていた ことから，二座配位硫酸塩が光触媒反応の不活性化 に寄与していることを見い出した.

詳細な $2 \mathrm{CEES}$ の $\mathrm{TiO}_{2}$ 表面上への吸着状態及び 表面上における分解機構に関する研究は, Yatesら により超高真空中にて行われ，2003-2004 年に結果 が報告されている．Yates らは大表面積光触媒とし て $\mathrm{TiO}_{2}-\mathrm{SiO}_{2}$ 粉末状光触媒を使用している. $2 \mathrm{CEES}$ は $\mathrm{Cl}$ 及び $\mathrm{S}$ 基が $\mathrm{TiO}_{2}-\mathrm{SiO}_{2}$ 光触媒表面上の Isolat- 
ed $\mathrm{Ti}-\mathrm{OH}$ 及び $\mathrm{Si}-\mathrm{OH}$ ，つまり塩基性表面水酸基に 水素結合することで吸着することを見い出した. ${ }^{30}$ 光触媒反応により 2 CEES は分解されるが，検出さ れている表面化学種は，Klabunde ら ${ }^{28)}$ や Smirniotis ら 29) の研究グループが検出した中間体生成物と 同じであった．DESについても同様の実験を行つ ており，2CEESから得られた結果と比較しても反 応機構に大きな違いがみられないことを報告してい る。また，2CEESが分解されることで生成される $\mathrm{Cl}^{-}$イオンは，光触媒反応機構に影響しないことも 報告している.31) また，一度，2CEES を分解させ た光触媒に再度 2 CEES を導入しても吸着はほとん ど起こらず，酸化分解反応により生成された中間体 生成物が光触媒表面に蓄積することで再吸着が抑制 されることを見い出している，2CEES の $\mathrm{TiO}_{2}$ 表面 への吸着は, $124^{\circ} \mathrm{C}$ で熱処理することで回復するが,

2CEES の分解に対する光触媒活性は低下したこと から，Kozlov と Smirniotis ら25-27)により報告され ているように $\mathrm{TiO}_{2}$ 光触媒の不活性化が再確認され た. ${ }^{32)}$

同グループは, さらに $\mathrm{TiO}_{2}$ 光触媒表面上への 2CEES の吸着状態, 熱分解反応過程の研究を行い, 2004 年に結果を報告している。還元ルチル $\mathrm{TiO}_{2}$ 単 結晶表面に単層吸着した $2 \mathrm{CEES}$ は $2{ }^{\circ} \mathrm{C}$ 以上の温度 で吸着・脱離平衡状態になり，完全な脱離は $127^{\circ} \mathrm{C}$ 以上で起こることから，触媒表面上から脱離するの に必要な活性化エネルギーを $105 \mathrm{~kJ} / \mathrm{mol}$ と決定し
た。 すなわち, 室温では $\mathrm{TiO}_{2}$ 光触媒表面上に吸着 した 2CEES は脱離しないことを見い出した。また， 2CEES は， 88 から $268{ }^{\circ} \mathrm{C}$ の温度下で Isolated Ti$\mathrm{OH}$ や表面酸素格子である lattice TiO-H により酸 化され, $\mathrm{CH}_{3} \mathrm{CH}_{2}$ - $\mathrm{Ti}$ 及び $\mathrm{ClCH}_{2} \mathrm{CH}_{2} \mathrm{O}-\mathrm{Ti}$ に分解さ れる. $277{ }^{\circ} \mathrm{C}$ 以上では $\mathrm{HCl}$ や $\mathrm{ClCH}_{2} \mathrm{CH}_{3}$ が観察さ れている. ${ }^{33,34)}$

この Yates らの研究報告内容は，室温において $2 \mathrm{CEES}$ が $\mathrm{TiO}_{2}$ 光触媒表面上に強く吸着している理 由を明確にし， $80^{\circ} \mathrm{C}$ 以上の温度では，表面水酸基 や結晶酸素格子により光触媒酸化反応過程が影響さ れることを明示している. 上記の各研究グループは, 2CEES と DES の分解機構は類似していると報告し ているが，2CEES から少量ではあるが毒性のある b2ChED や，HD が触媒表面上で生成されることや， SEET や DESO の生成機構が DES で提案されてい るものと異なるなど，DES とはかならずしも同じ ではないようである，以上のことから $\mathrm{TiO}_{2}$ 光触媒 反応による 2CEES の分解機構について, Fig. 7 (c) にまとめた。

HD の擬似化学剂である DES 及び 2CEES の分解 に関する研究例は多くの研究グループにより報告さ れており，生成される中間体はかなり特定されてい る。本稿では明瞭になっている反応機構を Fig. 7 に示したが, Minor process が多数存在することも 提案されている. また，further oxidation に対応す る過程に関する詳細な研究も行われており, 光触媒

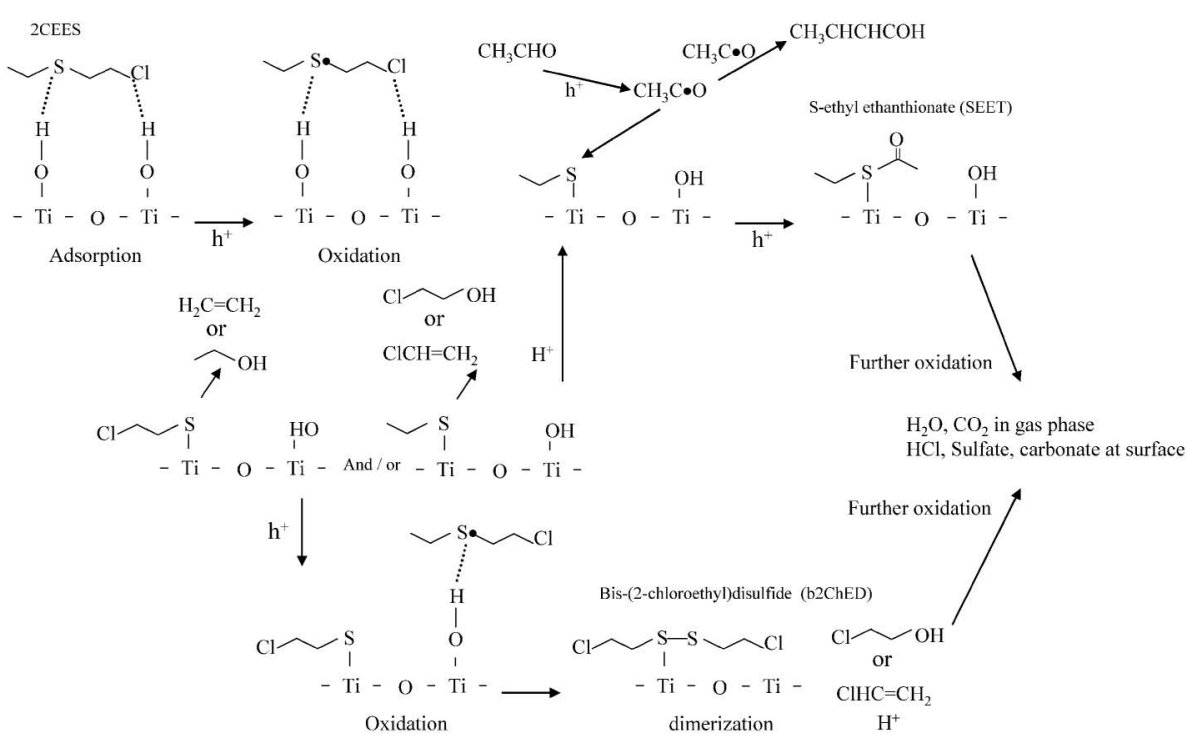

Fig. 7 (c). $\mathrm{TiO}_{2}$ Photocatalytic Oxidation Mechanism of 2 CEES 
反応により DES や 2CEES は完全に分解される。 したがって， $\mathrm{TiO}_{2}$ 光触媒を用いることで Fig. 5 に 示したような DVSや TG のような化合物を残すこ となく HD を確実に分解することが期待される.

4-3. GB, GD GB, GD に構造が類似する擬 似化学剂を光触媒により分解する研究は, ジエチル ホスホン酸 4-ニトロフェニル (4-NPDEP), リン酸 ジメチル-2,2-ジクロロビニル (DDVP) 及びホスホ ン酸ジメチル-2,2,2-トリクロロ-1-ヒドロキシエチル （DEP）を用いて 1987 年に Gratzel ら ${ }^{35,36)}$ 及び Tanaka ら37,38)により行われた。 Gratzel らは4NPDEP が光触媒表面上で分解される機構を観察 し, 光触媒分解反応中における $\mathrm{O}_{2}$ の機能や, $\mathrm{H}_{2} \mathrm{O}_{2}$ や $\mathrm{K}_{2} \mathrm{~S}_{2} \mathrm{O}_{8}, \mathrm{NaIO}_{4}, \mathrm{KBrO}_{3}$ の酸化剂と光触媒反応の 相乗効果を見い出した. ${ }^{35,36)}$ Tanaka らは水中にお いて DDVP 及び DEP のいずれも光触媒反応によ り分解され, $\mathrm{TiO}_{2}$ 表面への白金担持や $\mathrm{H}_{2} \mathrm{O}_{2}$ の添 加により分解速度が著しく向上することを見い出し た. ${ }^{37,38)}$ 構造にリンを有することから，1993 年には dichlorvos を光触媒で分解する研究も行われてい る. ${ }^{39)} こ の$ 後, 1997 年に O'Shea らにより, 化学構 造が GB に酷似しているメチルホスホン酸ジメチル (DMMP)（Table 4) が擬似化学剂として使用され, 光触媒による DMMP の分解に関する研究は現在ま で盛んに行われている. ${ }^{40)}$

O'Shea らは，水溶液中に溶解させた DMMPを $\mathrm{TiO}_{2}$ 光触媒反応により分解し, その分解機構につ いて 1997 年に報告している. ${ }^{40)} \mathrm{DMMP}$ は $\mathrm{TiO}_{2}$ 光 触媒反応により酸化されメチルホスホン酸メチル [MMP: $\mathrm{CH}_{3} \mathrm{P}(=\mathrm{O})(\mathrm{OH}) \mathrm{OCH}_{3}$ ] とメタノール $\left(\mathrm{MeOH}: \mathrm{CH}_{3} \mathrm{OH}\right)$ に分解され，MMP はメチルホ スホン酸 [MPA: $\mathrm{CH}_{3} \mathrm{P}(=\mathrm{O})(\mathrm{OH})_{2}$ ] に酸化され, 最終的に $\mathrm{TiO}_{2}$ 光触媒反応では分解できないリン酸 $\left(\mathrm{PO}_{4}^{-}\right)$にまで酸化されることを見い出した。ま た，有機成分としてホルムアルデヒド $\left(\mathrm{FAh}: \mathrm{CH}_{2} \mathrm{O}\right)$, ぎ酸（FA: CHOOH）を検出しており，DMMP が 光触媒反応により確実に分解されることを確認して いる．また，アルカリ性水溶液中で DMMP を分解 する速度が向上することを見い出し，その理由とし て負に帯電した $\mathrm{TiO}_{2}$ 表面への DMMP の吸着量の 増加を提案している. ${ }^{40)}$

Smirniotis らのグループもまた，水溶液中におけ る $\mathrm{DMMP} の \mathrm{TiO}_{2}$ 光触媒分解機構を調查してい
る。観察された中間体生成物は，O’Shea ら 40$)$ から 報告されたものと同じであったが，Smirniotis らの グループは SPME 技術を用いることで，新たにヒ ドロキシル化された DMMP の中間生成物を多数検 出し, methyl methylphosphonic acid, dimethyl hydroxymethylphosphonic acid, methyl hydroxymethylphosphonic acid の生成を報告している。これら は少量の生成物であり，他に有機成分として FAh， FA を検出している. ${ }^{41}$

気化 DMMP を連続的にフローさせ, $\mathrm{TiO}_{2}$ 光触 媒反応による分解機構を調査した研究内容が，1998 年に Satyapal らにより報告されている. ${ }^{42)}$ 気化 DMMP は光触媒反応により $\mathrm{CO}_{2}$ と $\mathrm{CO}$ に分解され 気中に拡散することを見い出した，有機成分として $\mathrm{MeOH}, \mathrm{FA}$ が中間体として検出されている。 た, 光触媒表面上への MMP, MPA 及び $\mathrm{PO}_{4}^{3-} の$ 蓄積の観測とともに $\mathrm{TiO}_{2}$ 光触媒反応の不活性化が 観察されたことから，生成物の蓄積により光触媒が 不活性化されることを見い出した，不活性化した光 触媒は，水洗浄に加え新鮮な空気の下で長時間の光 照射を行うことで活性な状態に回復することも報告 している.

$\mathrm{TiO}_{2}$ 光触媒表面への DMMP の詳細な吸着過程 と, 表面上における光触媒反応機構に関する研究が, Yates らによりFTIR を用いて研究され 2000 年に 報告されている. ${ }^{43,44)}$ DMMP は蒸気圧が低いため 容易に $\mathrm{TiO}_{2}$ 表面へ堆積し，DMMP の $\mathrm{O}=\mathrm{P}$ 基の $\mathrm{O}$ 原子が $\mathrm{TiO}_{2}$ 表面上の Lewis 酸 $\mathrm{Ti}$ サイト又は塩 基性水酸基（ $\mathrm{TiO}-\mathrm{H} ）$ に吸着する。吸着した DMMP は，214 K 以上の温度，すなわち室温で は，吸着サイト近辺にある塩基性水酸基により DMMP の- $-\mathrm{CH}_{3}$ 基の 1 つが加水分解され MMP を形成することを見い出した．MMP は DMMP が 光触媒により酸化されることでも生成される．生成 された MMP の $\mathrm{OH}$ 基が光触媒表面に吸着するこ とで吸着 MMP を形成するが，吸着 MMP の形成 とともに, $\mathrm{Ti}-\mathrm{O}-\mathrm{CH}_{3}$ が光触媒反応により酸化され て formate（Ti-OOCH）を中間体として生成するこ とも観察している．また，DMMP の多量な吸着に より，光触媒反応が抑制されることも見い出してい る.

Hoffmann らのグループは, 熱処理された $\mathrm{TiO}_{2}$ 表面への DMMP の吸着による水酸基の挙動や，生 
中間体生成物について DRIFTS を用いて研究し, その内容を 2005 年に報告している. ${ }^{45)}$ 熱処理 $\mathrm{TiO}_{2}$ 表面では，DMMP の吸着及び加水分解が抑制され ていることを見い出した.これは光触媒表面上の水 酸基量の低下により加水分解量が低下するのに加 え，表面吸着水の減少による DMMP の可溶量が低 下したためと考察されている。これとは反対に熱処 理を行わずに紫外線で照射した $\mathrm{TiO}_{2}$ では，DMMP の吸着及び加水分解が促進されることを見い出して いる．また， DMMP から MPA への光触媒反応に よる分解は進行し易いが，MPA から $\mathrm{PO}_{4}^{3-}$ への酸 化には長時間を必要とすることを見い出している.

Vorontsov らのグループは，暗所における DMMP の吸着過程及び $\mathrm{TiO}_{2}$ 光触媒反応における 分解機構の湿度（低湿度： $1 \%$, 高湿度 : $50 \%$ ）及 び DMMP の濃度依存性について研究し，2005 年 に報告している。 ${ }^{46)}$ 低湿度・暗所条件において, $\mathrm{TiO}_{2}$ 表面へ DMMP の吸着が終了したのち， $\mathrm{MeOH}$ が触媒表面で観測されていたことから, 加 水分解は比較的緩やかに進行していることを見い出 した，高湿度では DMMP の吸着量は増大し，それ に伴い加水分解の進行も早くなり，DMMP は $\mathrm{MeOH}$ と MMP に完全に分解されることを見い出 した。また，生成された $\mathrm{MeOH}$ は $\mathrm{H}_{2} \mathrm{O}$ と置換され 気中に拡散した。高濃度の DMMP 吸着においても 加水分解で生成した $\mathrm{CH}_{3} \mathrm{OH}$ 及び $\mathrm{Ti}-\mathrm{OOCH}$ が DMMP により置換され気中に脱離させられること を見い出している. DMMP の吸着飽和後, 光触媒 反応を開始することで，いずれの条件下においても DMMP は $\mathrm{CO}_{2}$ と $\mathrm{PO}_{4}^{3-}$ に分解された。 その際，低 湿度・低濃度 DMMP において, 表面に中間体とし て Ti-OOCH，気中で $\mathrm{CO}_{2}$ が検出されている．低湿 度・高濃度 DMMP の場合には，気中に拡散した主 要生成物は $\mathrm{CO}$ であり，ほかに $\mathrm{CO}_{2}, \mathrm{FA}, \mathrm{H}_{2} \mathrm{O}$ が観 測されており，高湿度の条件にした場合には，これ ら中間生成物の生成量は低下した。これは表面の物 理吸着水量の増大による光触媒反応速度の低下によ るものであると考察している.

上記で紹介した多くの研究グループは, Degussa P25 や大表面積である Hombikat UV100 などを $\mathrm{TiO}_{2}$ 光触媒として用いているが，気中及び液中い ずれにおいても，DMMP の分解機構に大きな違い はみられていない。このほかにも，XPS を用いて
$\mathrm{TiO}_{2}$ 単結晶上に吸着した DMMP の分解機構に関 する研究結果が 2003 年に報告されており, IRから 得られた結果を支持する内容が報告されている. ${ }^{47)}$ $\mathrm{GB}$ と同じく化学構造に $\mathrm{F}$ を有し危険性が高い擬似 化学剂であるフルオロホスホン酸ジイソプロピル （DFP）を用いた研究も 2005 年から Osterlund らに より行われている. ${ }^{48,49)}$ DFP の基本的な分解機構は DMMP と同じであり，構造に含まれる $\mathrm{F}$ は加水分 解され Ti-F を形成することが見い出されている.

このように，DMMP 及び DFP を用いた研究か ら，Fig. 4 に示したような MIPP のような化合物も 光触媒により分解されることが期待されている.

Figure 8 には上記した研究報告から要約された $\mathrm{TiO}_{2}$ 光触媒反応による DMMP の分解機構を示し た.

4-4. GA 構造中に $\mathrm{CN}$ を有する $\mathrm{GA}$ を $\mathrm{TiO}_{2}$ 光触媒反応により分解する研究は, GA の化学構造 が GB に類似しているという観点から，DMMPを 用いた研究として一括りに考えられており，研究報 告例は非常に少ない，唯一，Smirniotis らのグルー プが，化学構造に $\mathrm{NH}_{2}$ を含む diethyl phosphoramidate (DEPA) を GA の擬似化学剤として用いて 研究を行い，2002 年に結果を報告している. ${ }^{41)}$ DEPA は揮発性が低いため反応は水溶液中で行わ れている。生成物として $\mathrm{NH}_{4}^{+}$や $\mathrm{NO}_{3}^{-}$が検出され ている。 その他に, 2-hydroxyethyl ethylphosphoric acid, 2-hydroxyethyl ethylphosphoramidate, ethylphosphoramidate, bis (2-hydroxyethyl) phosphoric acid，リン酸ジエチル，リン酸エチル及び $\mathrm{PO}_{4}^{3-}$ が 検出されている，有機成分として EtOH，Ac 及び $\mathrm{AC}$ が検出されている，報告の中では，DEPA 構造 に含まれるアミノ基は光触媒反応に大きく影響しな いと結論付けている. 提案されている $\mathrm{TiO}_{2}$ 光触媒 反応による DEPA の分解機構を Fig. 9 に示す.

4-5.VXVXの擬似化学剂を用いた研究もま た，VXの化学構造が GB に類似しているという観 点から，DMMPを用いた研究として一括りに考え られており，報告例は非常に少ない。唯一，Smirniotis らのグループが化学構造に $\mathrm{S}$ 及び $\mathrm{N}$ を含んで いる 2-(ブチルアミノ) エタンチオール（BAET） を擬似化学剂として用いて研究を行い，2002 年及 び 2004 年に結果を報告している. ${ }^{41,50)} \mathrm{VX}$ は $\mathrm{P}=\mathrm{O}$ を骨格にした化学剤であるが，BAETはVXの化 


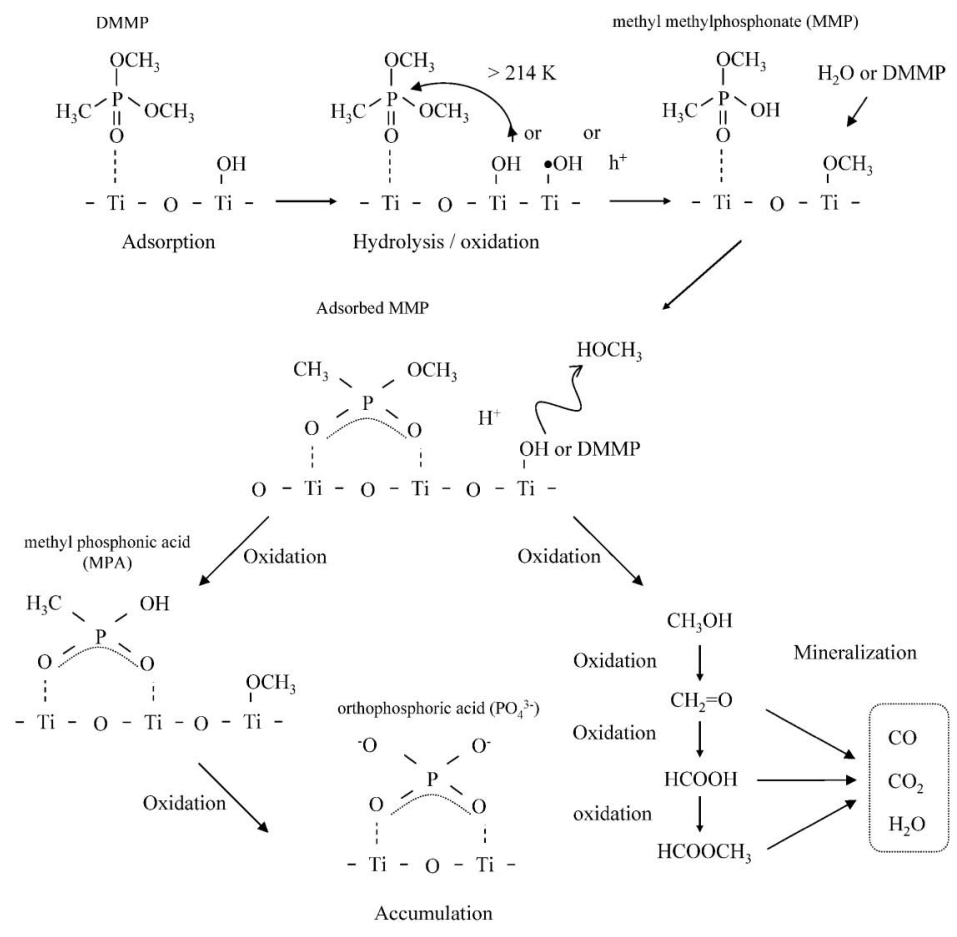

Fig. 8. $\mathrm{TiO}_{2}$ Photocatalytic Oxidation Mechanism of DMMP

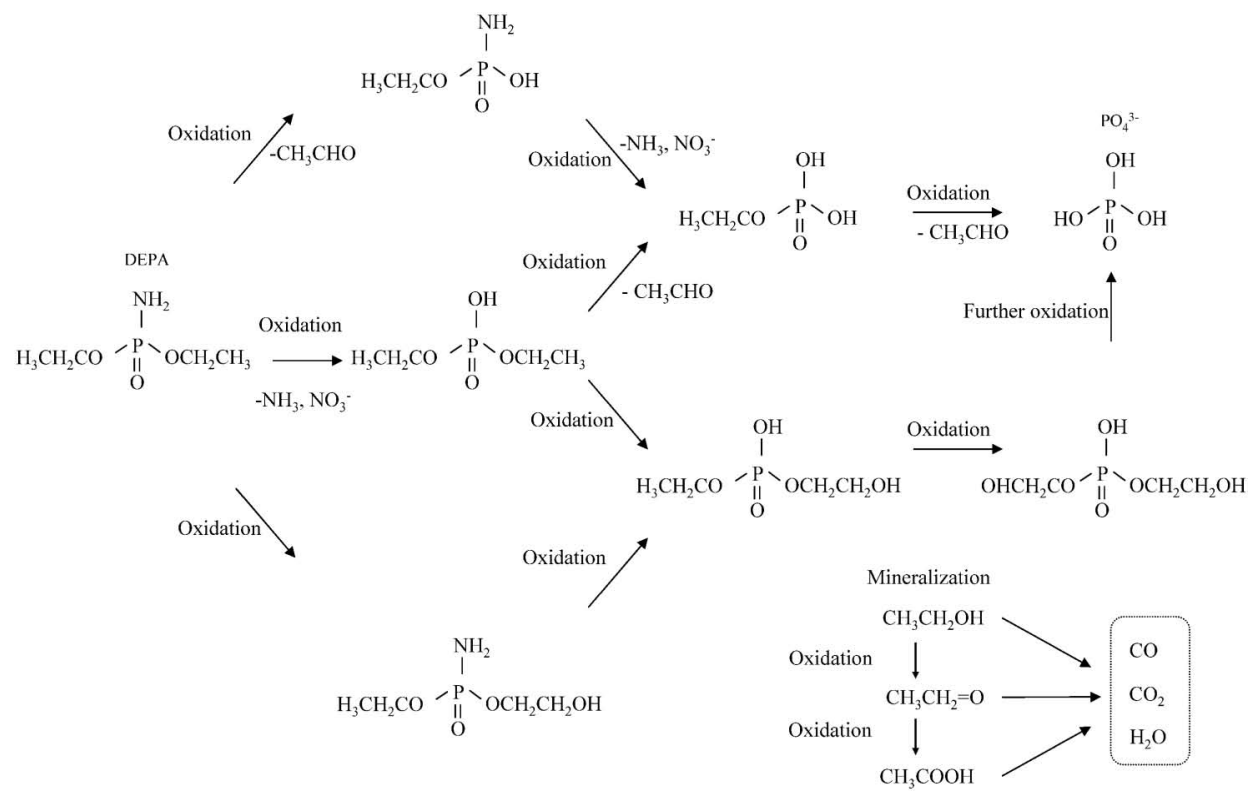

Fig. 9. $\mathrm{TiO}_{2}$ Photocatalytic Oxidation Mechanism of DEPA

学構造で毒性を示す $\mathrm{SCH}_{2} \mathrm{CH}_{2} \mathrm{~N}\left(\mathrm{CH}\left(\mathrm{CH}_{3}\right)_{2}\right)_{2}$ 基の 分解に着目した研究である. BAET は VX と同様 に揮発性が低いため, 研究内容は水溶液中に限定さ れている. 暗所において BAET は $\mathrm{TiO}_{2}$ 光触媒表面 に接触することで 2 量化して dimmer BAET [DBAET: $\left(\mathrm{CH}_{3}\left(\mathrm{CH}_{2}\right)_{2}-\mathrm{NH}-\mathrm{CH}_{2} \mathrm{CH}_{2}-\mathrm{S}\right)_{2}$ ] を形成
し, この DBAET が光触媒反応により分解される ことは困難であることを見い出している。また BAET に対する光触媒活性は，水溶液の $\mathrm{pH}$ が 9.1 以下で著しく低下することが見い出されている．提 案されている $\mathrm{TiO}_{2}$ 光触媒反応による BAET の分解 機構を Fig. 10 に示す. 


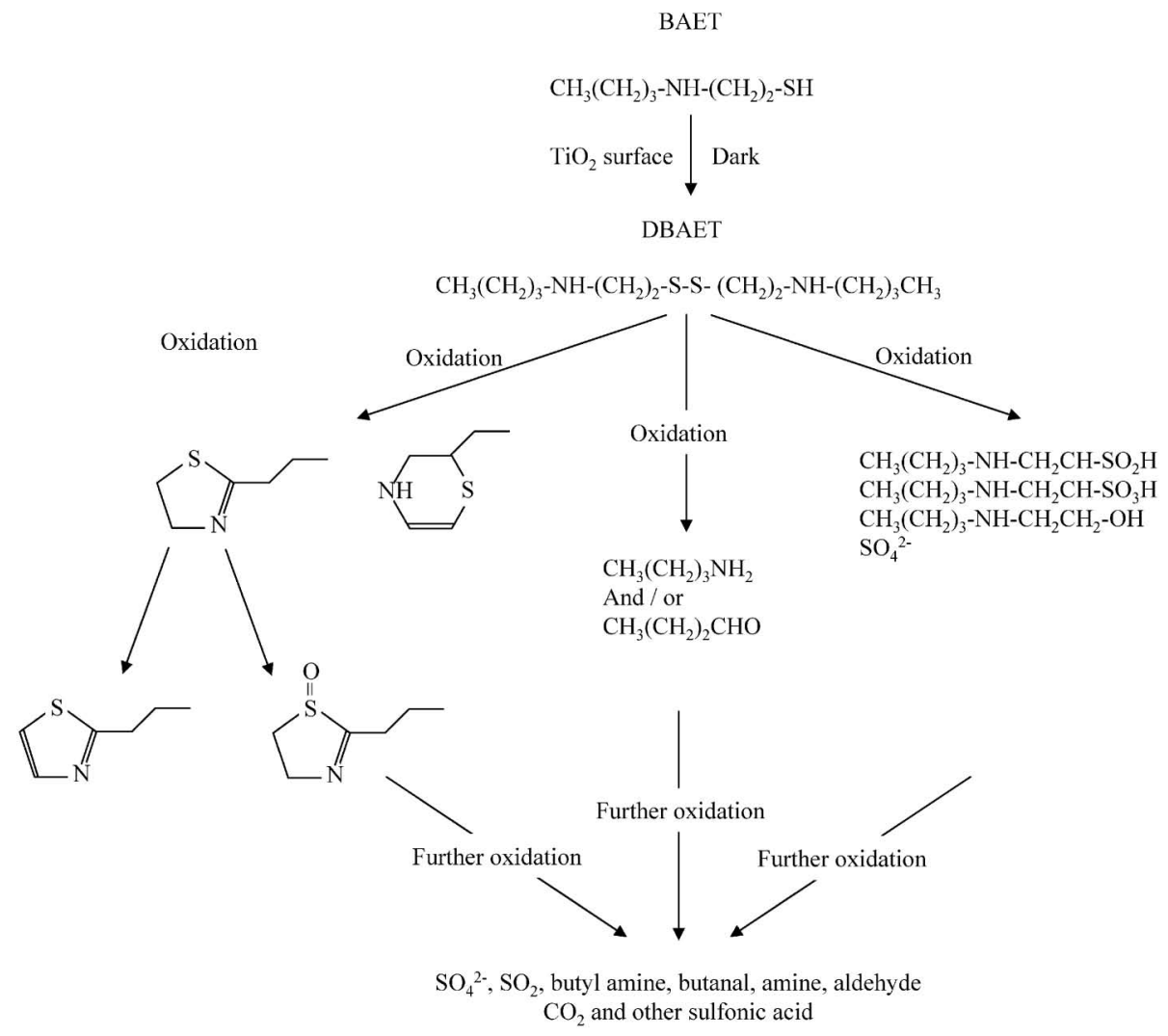

Fig. 10. $\mathrm{TiO}_{2}$ Photocatalytic Oxidation Mechanism of BAET

4-6. 光触媒反応による擬似化学剤と実化学剤の 分解 $\mathrm{TiO}_{2}$ 光触媒により擬似化学剂を分解する 研究のこれまでの経緯と明確になった点を述べた。 擬似化学剂を用いることで $\mathrm{TiO}_{2}$ 光触媒反応による 実化学剂の分解機構が推測できるようになった。し かしながら, 実化学剤と擬似化学剂では, Table 3 と Table 4 から分かるように, 化学構造が異なるこ とから, 光触媒反応機構が異なることが容易に推測 される.

例えば，HD の擬似化学剂の DES, 2CEES につ いても，化学構造に $\mathrm{Cl}$ が入ることで光触媒分解機 構や，生成される中間体生成物の毒性など，両化合 物において異なる点がみられる。また，2CEES と $\mathrm{HD}$ を $\mathrm{CaO}$ 粉末により加水分解させた場合におい て HD は継続的に加水分解されるのに対し, 2CEES の場合には所定時間後に停止するという違 いが観察されている。これは吸着過程及び $\mathrm{Cl}^{-}$が $\mathrm{CaO}$ を溶解させるためと提案されている. したが

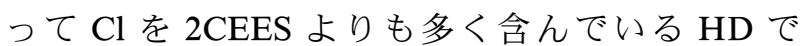
は, 光触媒表面上への吸着状態, 反応機構, 生成さ れる中間体生成物とその毒性が異なると容易に推測
され，2CEES や DES から推測された分解機構と同 じにはならないであろう。

研究報告例が多く, 分解機構が明確である DMMP においては，GB，GD の構造に含まれる F の影響 が検討されていない. DEP を用いた研究から Ti-F の形成が XPS によって確かめられているが，光触 媒反応に与える影響は明らかにされていない。 Ti-F は光触媒反応により生成される活性酸素種である $\mathrm{OH}$ ラジカルの生成量を増大させると報告されてい るのに加え, ${ }^{51,52)} \mathrm{GB}$ の加水分解が抑制されること が固体酸化物表面上に GB を吸着させる研究から報 告されている. ${ }^{13)}$ 吸着状態の変化は光触媒反応機構 を変化させるが，MPA や $\mathrm{PO}_{4}^{3}$-の蓄積との関係も 含め, Ti-F の影響を分解機構や触媒活性に対して 研究する必要があるだろう。

DEPA は G 剂の GA の擬似化学剂として用いら れているが，CN を構造に含んでいない。したがつ て，生成される中間生成物や反応機構が異なること は容易に推測される，特に気中においては，HCN ガスの生成なども懸念される.

BAET は化学構造に $\mathrm{O}=\mathrm{P}$ 基を有していない. 
$\mathrm{VX}$ は， $\mathrm{O}=\mathrm{P}$ 基を有するため， $\mathrm{PO}_{4}^{3-}$ に分解され ると考えられ，BAET とは反応機構が異なるだろ う。また，Fig. 7, 10 に示したように，分解機構は DMDS などを生成した 2CEES や DES に類似する だろう。したがって，VXの分解機構は DMMP と 2CEES 又は DES の両方が同時に進行する過程を想 定する必要があり， $\mathrm{PO}_{4}^{3-}, \mathrm{S}$ 及び $\mathrm{N}$ が光触媒を不 活性化する可能性が推測される。しかしながら， $\mathrm{TiO}_{2}$ 光触媒反応により $\mathrm{VX}$ が危険な中間体を生成 せずに確実に分解されるかなどを含め不明な点が多 い.

Figure 11 には擬似化学剤により明らかになった 点及び不明な点についてまとめたが，実化学剤を用 いた実証研究例がかならず必要なことが明確であろ う。また, $\mathrm{TiO}_{2}$ 光触媒反応の欠点として, 分解生 成物の蓄積による光触媒の不活性化が DES,

2CEES 及び DMMP を用いた研究から明確にされ ている。不活性化 $\mathrm{TiO}_{2}$ 光触媒は，水洗浄，硫酸水 溶液洗浄や紫外線照射により再活性化することも報 告されているが，完全な回復ではないことから化学 剂分解に対する $\mathrm{TiO}_{2}$ 光触媒の限界を見極める必要 があることも，過去の多くの研究結果は示している.

\section{5. 当所における研究}

当所では 1980 年ごろから半導体光触媒の作用と 空気浄化への応用を検討してきた，無機・有機の大
気污染物質の分解機構, 光触媒の固定化・材料化, 浄化システムの提案などを行ってきたが，化学剂処 理は新規分野であることと，化学剂そのものを所内 で扱うことができないために，擬剂の分解から検討 し，共同研究先である科学警察研究所の施設を利用 して，実剤処理の検討を始めたところである．基礎 的な知見に基づいて，最終的には種々の除染システ ムを開発することを目指しているが，ここでは途中 経過を紹介する.

5-1. 擬剂の分解 (DMMP) GB の擬剂であ る DMMP を選択し，既往の研究を追試するところ から検討を始めた。分解実験には，Fig. 12 に示す ようなバッチ式の気相反応装置を用いた．本来なら ば，流通式反応器の方が再現性もよくまた反応生成 物の分析にも有利であるが，擬剤であっても無害で はないこと，また次のステップで用いる実剂も量が 限られていることを考慮して，バッチ式とした。液 体の DMMP に空気をバブリングすることで，低濃 度の DMMP ガスを発生させて，容積 $200 \mathrm{ml}$ の Pyrex 製ガラス容器に導入した，光触媒は粉末を水や アルコールに溶いたものを $50 \mathrm{~mm}$ 角のすりガラス に $10 \mathrm{mg}$ となるようにコーティングして乾燥・固 着させた。これを反応容器内に置いて，空板を介し て上方より光照射を行った，光触媒としては，デフ アクトスタンダードとなった Degussa P25 に加え

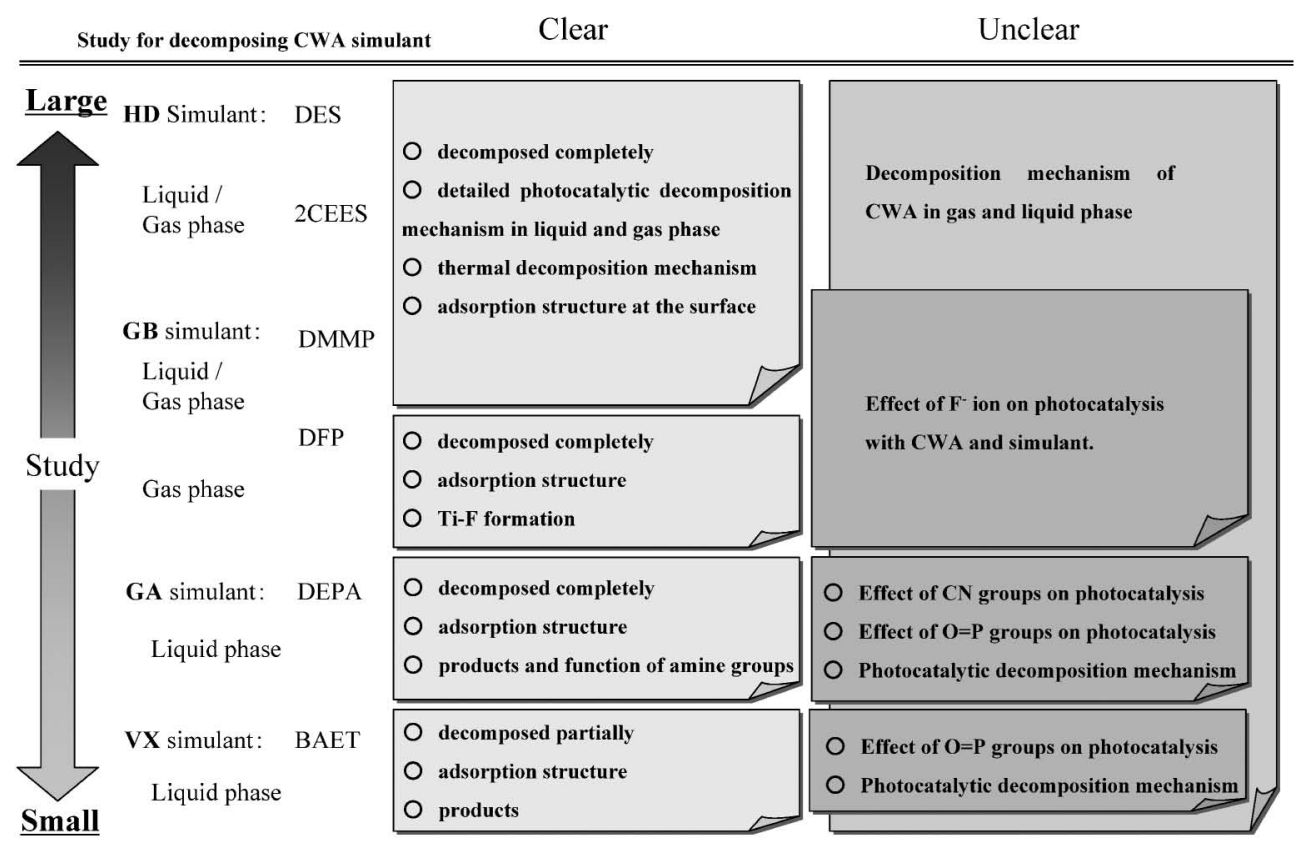

Fig. 11. Summary of Clear and Unclear Points on $\mathrm{TiO}_{2}$ Photocatalytic Decomposition of Several CWA Simulants 
て，当所が開発した可視光応答型光触媒などを用い た。 DMMP 及び生成物は FID ガスクロマトグラフ (GC) やガスクロマトグラフー質量分析計 (GCFID）を用いて分析した.

最初に遭遇した問題は DMMP が安定に気化しな いことであった．DMMP の沸点が $180^{\circ} \mathrm{C}$ と， GB のそれ $\left(158^{\circ} \mathrm{C}\right)$ よりも高いこともあるが, 反応容 器壁などへの吸着が非常に強いことが分かった。こ のため, 反応器をヒーターで $90{ }^{\circ} \mathrm{C} に$ 加熱して, 吸 着を軽減させた. 反応器内面のシランコーティング やシール材の変更（シリコーンーテフロン PTFE） も有効であり, 反応器の加熱が必須ではなくなった.

光照射なしに光触媒と接触しただけでもいくつか の生成物が検出されたが，光照射を行うと，少なく とも 8 種類の生成物が検出され, さらに光照射を続 けるとそれらの量は減少した。 代表的なクロマトグ ラムを Fig. 13 に示す。メタノールやぎ酸が同定さ れているが，基本的にはより小さな分子へと分解さ れており，有害な物質が新たに生成することはない

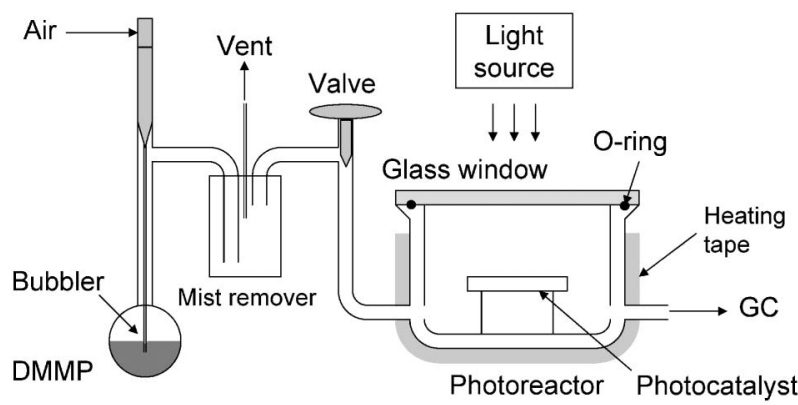

Fig. 12. Experimental Setup for Photocatalytic Decomposition of CWAs
と考えられた.

しかし, 反応後に再び DMMP を導入し, 光触媒 反応を繰り返すと次第に分解速度が低下することが わかった. Figure 14(a)に示すように，光照射前の 吸着量は逆に増加した。DMMP の分解で生成した リン酸が酸化チタンに結合し, 光触媒活性を低下さ せるとともに，気相りん化合物との親和性を高める など，表面の性質を変化させるためと考えられた．

DMMP にはないが，GB にはフッ素が含まれて いるため, 同様に光触媒表面の性質が変わる可能性
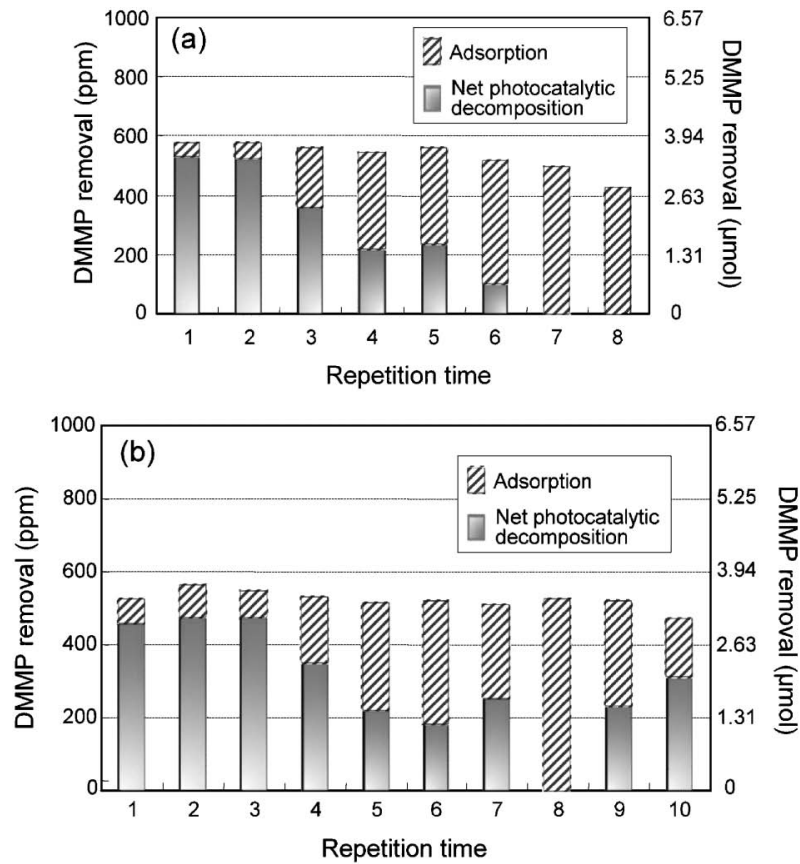

Fig. 14. Repeated Cycles of Adsorption and Photocatalytic Decomposition of DMMP over $\mathrm{TiO}_{2}$.

(a): Normal $\mathrm{TiO}_{2}(\mathrm{P} 25)$, (b): Fluorine-treated $\mathrm{TiO}_{2}$.

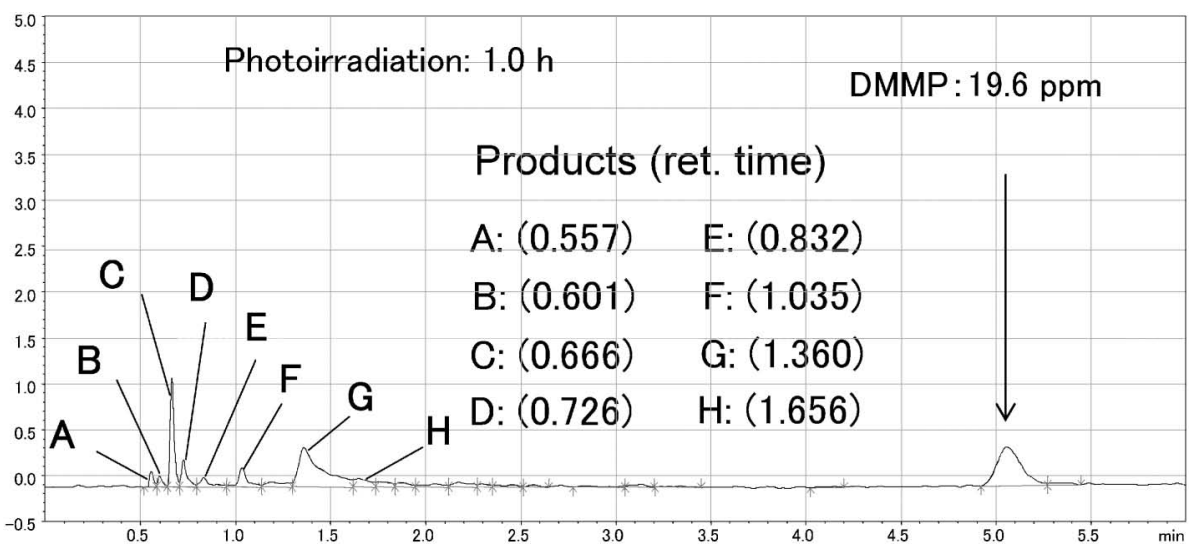

Fig. 13. Typical Chromatogram of DMMA Decomposition Products 
がある.このため，フッ化ナトリウムを用いてあら かじめ表面を改質した酸化チタンで DMMP の繰り 返し光触媒分解を検討した. Figure 14(b) に示すよ うに，分解速度の低下は抑制され，ばらつきはある ものの光触媒活性は一定に近付いているようにみえ る.

以上のことから，対象物質にも依存するが，光触 媒反応によって揮発性の低い物質が生成すると，活 性低下（一種の被毒）が起こることが明らかとなつ た。しかし，化学剂処理に用いた光触媒の再利用を 考える必要はなく，吸着除去だけでも気相濃度の低 減という目的は果たせるといえる，光触媒単位質量 当たりの処理能力をきちんと評価して，除染システ ムの設計に役立てることが重要といえよう。

5-2. 擬剂の分解（有機リン化合物） 前項で は気相物質の処理を示したが，実際の除染作業にお いては大量の廃液が発生し，その中の化学剂等も痕 跡量以下に低減させる必要がある。このため，有機 リン系農薬を擬剂として水中の光触媒反応を検討し た。実験では，光触媒ビーズを充填したらせん状ガ ラス管（内径 $6 \mathrm{~mm}$ ，長さ $900 \mathrm{~mm}$ ）を用い，紫外 線を照射しながら，模擬污染水を循環させる方法を 取った。

Figure. 15 に示すように, Acephate $\left[\mathrm{CH}_{3} \mathrm{CONHP}\right.$ $\left.=\mathrm{O}\left(\mathrm{OCH}_{3}\right) \mathrm{SCH}_{3}\right]$, dimethoate $\left[\mathrm{CH}_{3} \mathrm{NHCOSP}=\mathrm{S}\right.$ $\left.\left(\mathrm{OCH}_{3}\right)_{2}\right]$, glyphosate $\left[\mathrm{HOOCNHP}=\mathrm{O}(\mathrm{OH})_{2}\right]$ と もに，光照射とともに水中から消失していくのが分 かる．ただ，glyphosateだけは光照射なしでも同様 に減少しており, 酸化チタン光触媒への吸着が非常 に強いことが示された。イオンクロマトグラフを用 いて溶液を分析すると， glyphosate の場合を除い て，硫酸やぎ酸が検出された。いずれの農薬の反応
からも，硝酸イオンが誘導期間を経て検出された. 一方，反応後もリン酸イオンは検出されず，水中で も酸化チタンに強く吸着されるものと考えられた. 今後, 反応速度や共存物質の影響を精査する必要は あるが，除染廃液についても，光触媒処理が可能で あることが示されたといえる。

5-3. 実剤の分解 以上の結果を踏まえ, 科学 警察研究所において，実際の化学剂の光触媒分解の 検討を開始した。予備的実験で GB などが分解する ことを確認できたが，バッチ式反応器では吸着と分 解を明確に区別することが難しい。このため，光触 媒の量を減らすことで，吸着量を低減させることを 試みた。

Figure 16(a) は酸化チタン $10 \mathrm{mg}$ の場合であり, 吸着によって光照射前に GB の気相濃度がほとんど ゼロとなり，光照射の影響が分からない。酸化チ夕 ン量を $1 / 20$ の $0.5 \mathrm{mg}$ としたところ，Fig. 16(b)よ うに，速やかに吸着平衡が得られて，光触媒による 分解が明らかとなった．光触媒反応はほぼ一次反応 速度式で整理され，約 45 分で GB 濃度は $1 / 100$ に なることが分かった。酸化チタンが $1 / 100$ 量（0.1 $\mathrm{mg}$ ）の場合には，光触媒反応による GB の分解は 進行するが，3 時間ほどで分解が停止していた [Fig. 16(c) ]。重量を $1 / 1000$ 量 $(0.01 \mathrm{mg})$ まで減 らすと，光照射初期まもなく分解が停止することが 分かった [Fig. 16(d)]。DMMP の実験結果と考え 合わせ，生成するリン化合物の蓄積が反応を停止さ せたものと推測された。

$\mathrm{GB}$ は加水分解を受け易く，処理は比較的容易と されている。そこで分解され難いマスタードガス （HD）を処理できるかどうかが注目されていた. HD も非常に吸着が強い物質であるが，GB 同様に
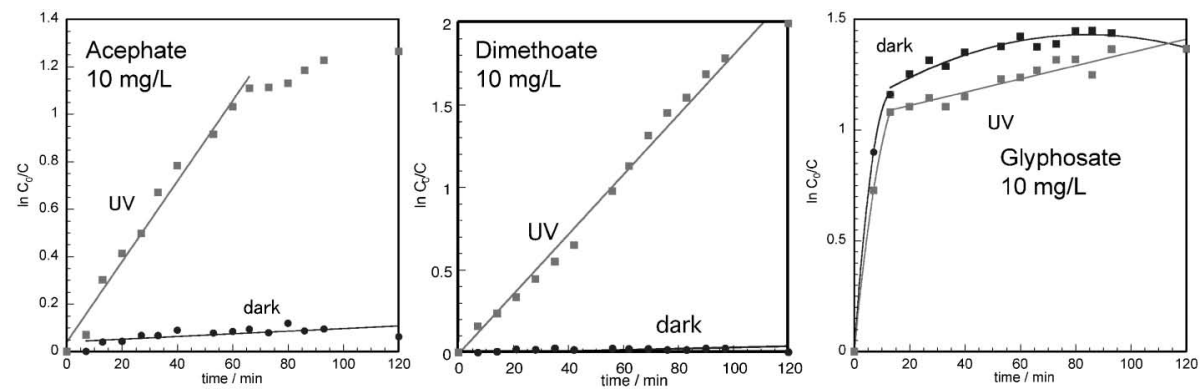

Fig. 15. Removal of Pesticides in Aqueous Phase by Photocatalysis as Determined by Total Organic Carbon (TOC) Measurement. Reactor, $6 \mathrm{~mm}$ i.d. $\times 900 \mathrm{~mm}$, photocatalyst: Shinto V Cerax HQC22 $(14 \mathrm{~g})$, volume of solution: $200 \mathrm{ml}$, UV-A: FL-6BLB. 

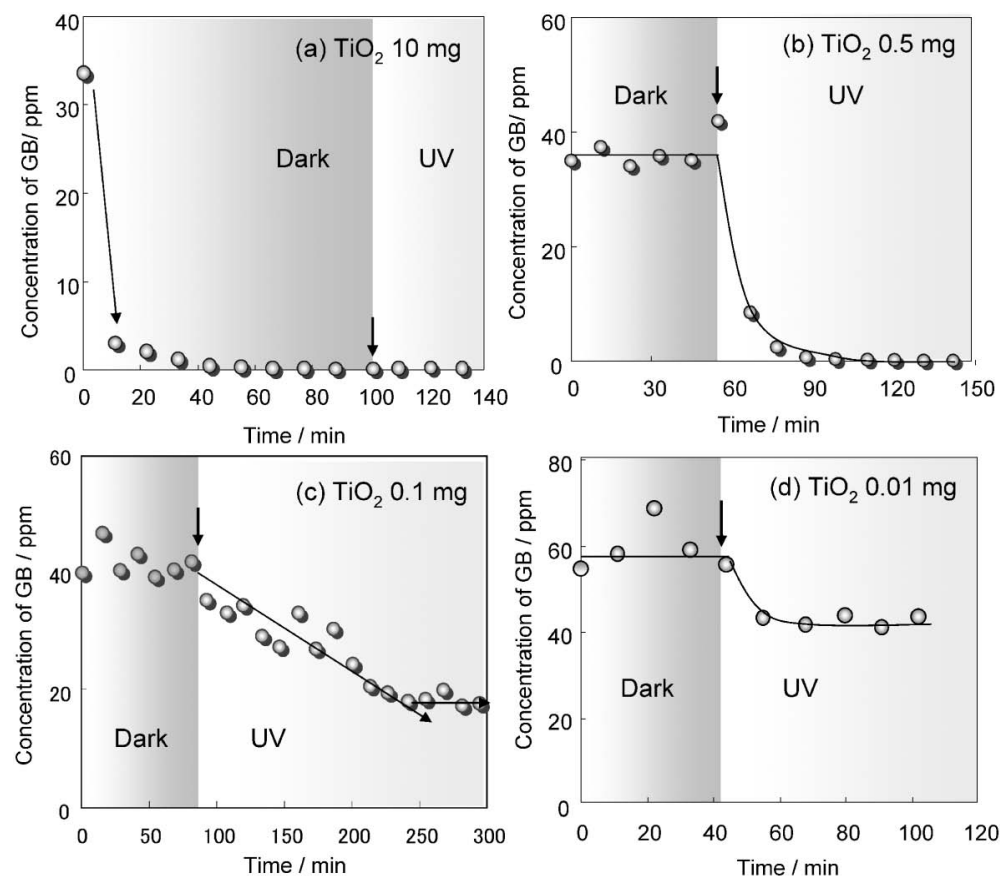

Fig. 16. Change of GB Concentration with $\mathrm{TiO}_{2}$ Photocatalyst Photocatalyst: P25 on glass $(50 \times 50 \mathrm{~mm})$, UV-A: $6 \mathrm{~mW} / \mathrm{cm}^{2}$.

酸化チタン量を減らしていくことで, 光触媒で分解 することを明らかにすることができた. Figure 17 に示すように, 酸化チタン $0.001 \mathrm{~g}$ でも暗時の平衡 に長時間を要するほど吸着力が大きいが，光照射後 の減衰は明らかである。

\section{6. おわりに}

光触媒による有害化学物質の応用として, 化学剤 への適用例を調査し, 当所における予備的な実験結 果を紹介した，化学剂に限らず，光触媒反応はかな らずしも速いとはいえないが，低濃度であっても温 和な条件で処理できることが特徴である，実際のテ 口現場では初動の対応として, 大量の次亜塩素酸な どが散布されるため, 救助活動を行う側にとっても ダメージが大きいとのことである，今後，実剤によ る基礎デー夕を蓄積し，Fig. 18 に示すような有効 な除染システムの開発に活用する計画である。将来,

Fig. 3 に示した除染方法の中に，光触媒除染という 新しいカテゴリが取り入れられるように，光触媒の 可能性と限界を明確にするとともに，安全で確実な 除染技術として展開を図ることとしたい.

謝辞 本研究は文部科学省科学技術振興調整費 重要課題解決型研究プログラム「生物化学テロにお ける効果的な除染法の開発」において実施したもの

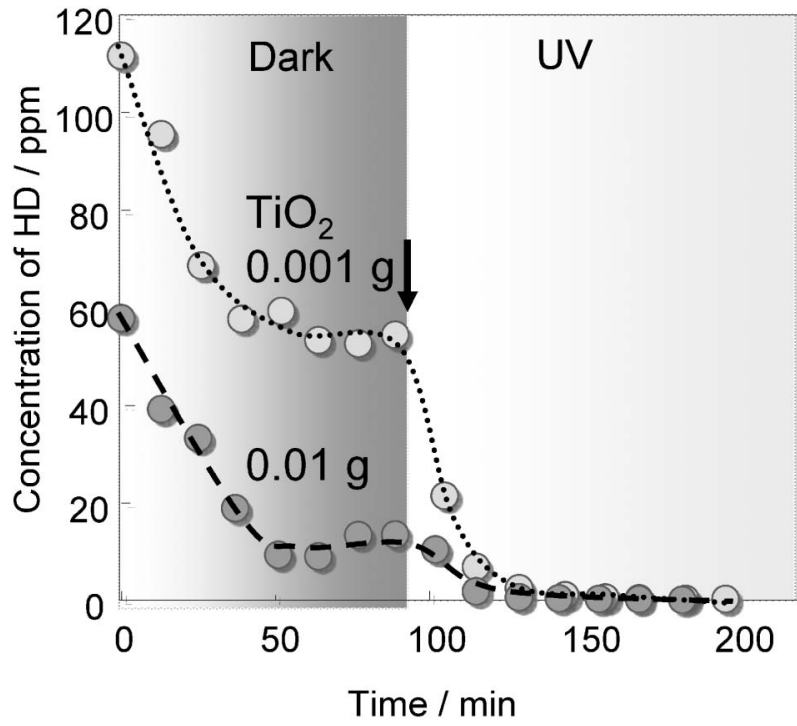

Fig. 17. Change of $\mathrm{HD}$ Concentration with $\mathrm{TiO}_{2}$ Photocatalyst

Photocatalyst: P25 on glass $(50 \times 50 \mathrm{~mm})$, UV-A: $6 \mathrm{~mW} / \mathrm{cm}^{2}$.

である. 研究の実施に当たり, 科学警察研究所の瀬 戸康雄博士並びに研究室の方々に多大のご指導・ご 協力を頂いた. ここに記して感謝の意を表する.

\section{REFERENCES}

1) Fujishima A., “'Zukai-Hikari Shokubai no Su- 


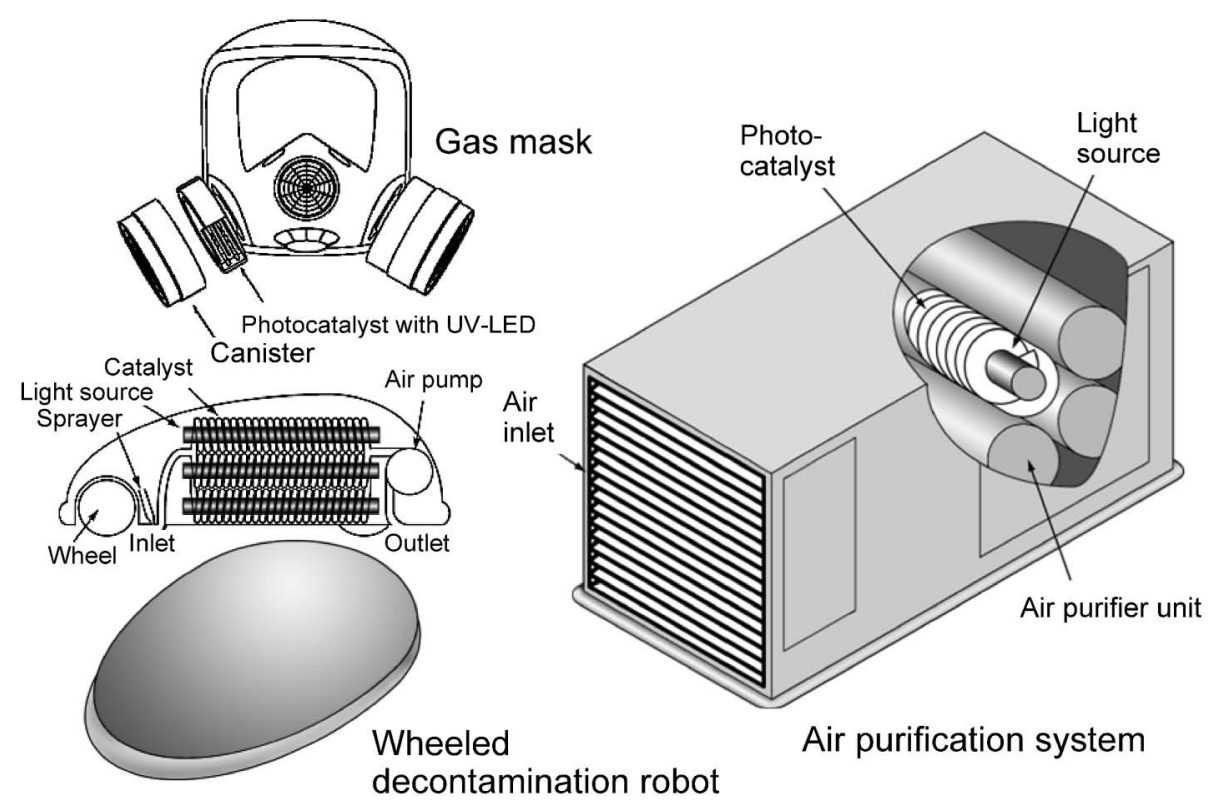

Fig. 18. Examples of Photocatalytic Decontamination Systems to Be Developed

bete”, ed. by Hashimoto K., Kougyo ChosaKai, 2003.

2) Herrmann J.-M., Catal. Today, 53, 115-129 (1999) .

3) Takeuchi K., Ibusuki T., "Hikarisyokubai Business Saizensen," Kougyo Chosa-Kai, 2001.

4) Nosaka Y., Nosaka Y. A., "Nyumon Hikarisyokubai," Tokyo, 77, 2004.

5) Sano T., Negishi N., Koike K., Takeuchi K., Matsuzawa S., J. Mater. Chem., 14, 380-384 (1994).

6) Seto Y., Yakugaku Zasshi, 126, 1279-1299 (2006).

7) Tu T. A., Inoue N., "'Overall View of Chemical and Biological Weapons," JIHOU, Tokyo, 2001.

8) "Hikkei Seibutsu Kagaku Terotaisyo Handbook," ed. by Fujimi S., Shindan to Chiryou Sya, Tokyo, 2005.

9) Yang Y.-C.,Baker J. A., Ward J. R., Chem. Rev., 92, 1729-1743 (1992).

10) Yang Y.-C., Szafraniec L. L., Beaudry W. T., Rohrbaugh D. R., Procell L. R., Samuel J. B., J. Org. Chem., 61, 8407-8413 (1996) .

11) Yang Y.-C., Acc. Chem. Res., 32, 109-115 (1999) .

12) Cassagne T., Cristau H.-J., Delmas G., Desgranges M., Lion C., Magnaud G., Torreilles
E., Virieux D., Heteroatom. Chem., 12, 485490 (2001).

13) Kuiper A. E. T., van Bokhoven J. J. G. M., Medema J., J. Catal., 43, 154-167 (1976) .

14) Ekerdt J. G., Klabunde K. J., Shapley J. R., White J. M., Yates Jr. J. T., J. Phys. Chem., 92, 6182-6188 (1988).

15) Wanger G. W., Bartram P. W., Koper O. B., Klabunde K. J., J. Phys. Chem. B, 103, 32253228 (1999).

16) Wanger G. W., Koper O. B., Erik L., Decker S., Klabunde K. J., J. Phys. Chem. B, 104, 5188-5123 (2000).

17) Wanger G. W., Procell L. R., Conner R. J., Munavalli S., Carnes C., Kapoor P. N., Klabunde K. J., J. Am. Chem. Soc., 123, 1636-1644 (2001).

18) Wanger G. W., Procell L. R., Munavalli S., $J$. Phys. Chem. C, 111, 17564-17569 (2007).

19) Yang Y.-C., CRDEC, 83-89 (1989).

20) Zuo G.-M., Cheng Z.-X., Li G.-W., Shi W.P., Miao T., Chem. Eng. J., 128, 135-140 (2007).

21) Zuo G.-M., Cheng Z.-X., Shi W.-P., Zhang X.-H., Zhang M., J. Photochem. Photobiol. A: Chem., 188, 143-148 (2007).

22) Davidson S. R., Pratt J. E., Tetrahedron Lett., 24, 5903-5906 (1983).

23) Fox M. A., Kim Y.-S., Abdel-Wahab A. 
A.,Dulay M., Catal. Lett., 5, 369-376 (1990).

24) Fox M. A., Abdel-Wahab A. A., Tetrahedron Lett., 31, 4533-4536 (1990).

25) Vorontsov A. V., Savinov E. V., Davydov L., Smirniotis P. G., Appl. Catal. B: Environ., 32, 11-24 (2001).

26) Vorontsov A. V., Savinov E. N., Claude L., Smirniotis P. G., Appl. Catal. B: Environ., 44, 25-40 (2003).

27) Kozlov D. V., Vorontsov A. V., Smirniotis P. G., Savinov E. N., Appl. Catal. B: Environ., 42, 77-87 (2003).

28) Martyanov I. N., Klabunde K. J., Envron. Sci. Technol., 37, 3448-3453 (2003).

29) Vorontsov A. V., Claude L., Savinov E. N., Smirniotis P. G., J. Catal., 220, 414-423 (2003).

30) Panayotov A. D., Yates Jr. J. T., J. Phys. Chem. B, 107, 10560-10564 (2003).

31) Panayotov A. D., Paul D. K., Yates Jr. J. T., J. Phys. Chem. B, 107, 10571-10575 (2003).

32) Panayotov A. D., Kondratyuk P., Yates Jr. J. T., Langmuir, 20, 3674-3678 (2004) .

33) Thompson L. T., Panayotov A. D., Yates Jr. J. T., J. Phys. Chem. B, 108, 16825-16833 (2004).

34) Thompson L. T., Panayotov A. D., Yates Jr. J. T., Martyanov I., Klabunde K., J. Phys. Chem. B, 108, 17857-17865 (2004).

35) Gratzel C. K., Jirousek M., Gratzel M., J. Mol. Catal., 39, 347-353 (1987).

36) Gratzel C. K., Jirousek M., Gratzel M., J. Mol. Catal., 60, 375-387 (1990).

37) Harada K., Hisanaga T., Tanaka K., New J. Chem., 11, 597-600 (1987).

38) Harada K., Hisanaga T., Tanaka K., Wat. Res., 24, 1415-1417 (1990).

39) Lu M.-C., Roam G.-D., Chen J. N., Huang
C. P., J. Photochem. Photobiol. A: Chem., 76, 103-110 (1993).

40) O’Shea K. E., Beightol S., Garcia I., Aguilar M., Kalen D. V., Cooper W. J., J. Photochem. Photobiol. A: Chem., 107, 221-226 (1997).

41) Vorontsov A. V., Dayvdov L., Reddy E. P., Lion C., Savinov E. N., Smirniotis P. G., New J. Chem., 26, 732-744 (2002).

42) Obe T. N., Satyapal S., J. Photochem. Photobiol. A: Chem., 118, 45-51 (1998).

43）Rusa C. N., Yates Jr. J. T., J. Phys. Chem. B, 104, 12292-12298 (2000).

44） Rusa C. N., Yates Jr. J. T., J. Phys. Chem. B, 104, 12299-12305 (2000).

45) Moss J. A., Szczepankiewicz S. H., Park E., Hoffmann M. R., J. Phys. Chem. B, 109, 19779-19785 (2005).

46) Trubistyn D. A., Vorontsov A. V., J. Phys. Chem. B, 109, 21884-21892 (2005).

47) Zhou J., Varazo K., Reddic J. E., Myrick M. L., Chen D. A., Anal. Chem., 496, 289-300 (2003).

48) Kiselev A., Andersson M., Mattson A., Shchukarev A., Sjoberg S., Palmqvist A., Osterlund L., Sur. Sci., 584, 98-105 (2003).

49) Kiselev A., Andersson M., Mattson A., Shchukarev A., Sjoberg S., Palmqvist A., Osterlund L., J. Photochem. Photobiol. A: Chem., 184, 125-134 (2006).

50) Vorontsov A. V., Chen Y.-C., Smirniotis P. G., J. Hazard. Mater., B113, 89-95 (2004).

51) Minero C., Mariella G., Maurino V., Pelizzetti E., Langmuir, 16, 2632-2641 (2000).

52) Minero C., Mariella G., Maurino V., Vione D., Pelizzetti E., Langmuir, 16, 8964-8972 (2000). 